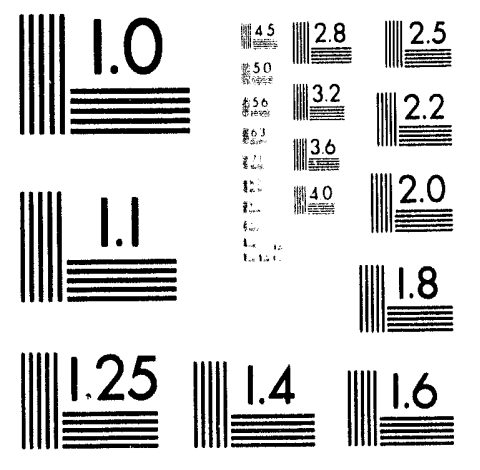



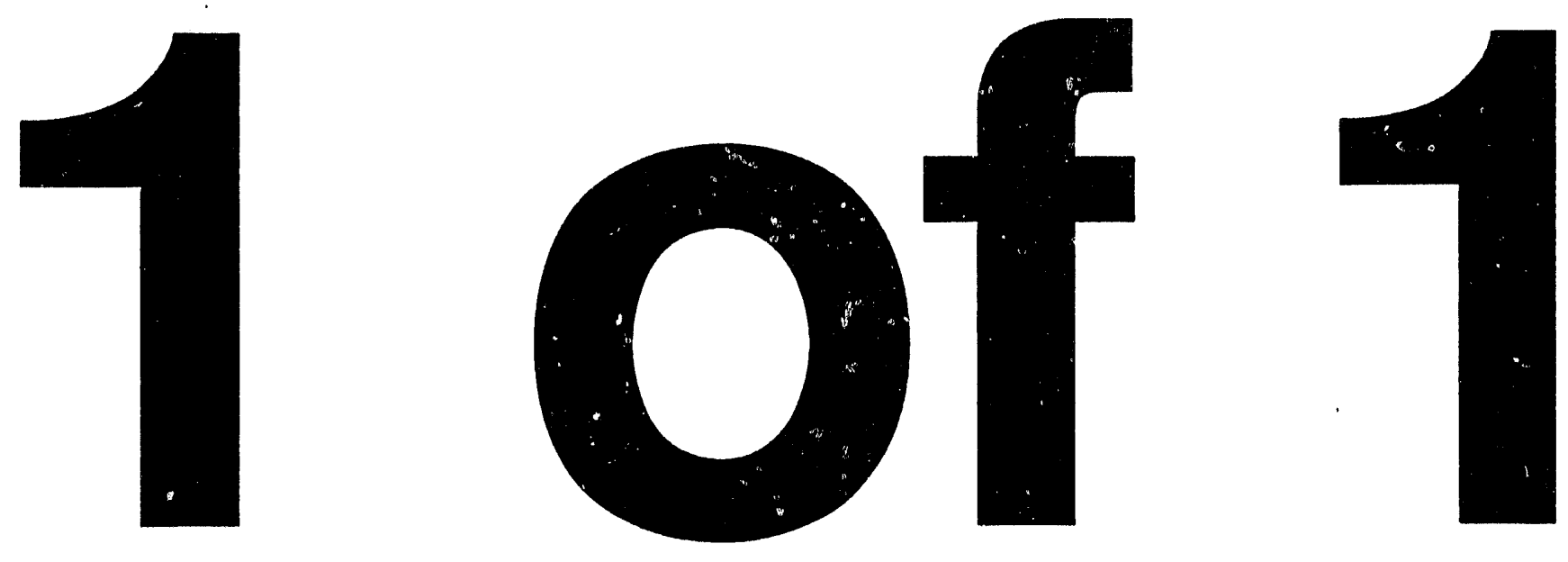
ARGONNE NATIONAL LABORATORY

9700 South Cass Avenue, Argonne, Illinois 60439

\title{
Preliminary Assessment Report for Wayland Army National Guard Armory (Former Boston Defense Area Nike Battery 73), Installation 23295, Wayland, Massachusetts
}

\author{
Prepared for \\ National Guard Bureau, Army Directorate \\ Aberdeen, Maryland
}

August 1993

Prepared by

Applied Geosciences and Environmental Management Section

Environmental Research Division

Argonne National Laboratory

DISCLAIMER

This report was prepared as an account of work sponsored by an agency of the United States Government. Neither the United States Government nor an, agency thereof, nor any of their employees, makes any warranty, express or implied, or assumes any legal liability or responsibility for the accuracy, completeness, or usefulness of any information, apparatus, product, or process disclosed, or represents that its use would not infringe privately owned rights. Reference herein to any specific commercial product, process, or service by trade name, trademark, manufacturer, or otherwise does not necessarily constitute or imply its endorsement, recommendation, or favoring by the United States Government or any agency thereof. The views and opinions of authors expressed herein do not necessarily state or reflect those of the United States Government or any agency thereof. 


\begin{tabular}{|c|c|}
\hline REPORT DOCUMENTATION PAGE & $\begin{array}{c}\text { FORM APPROVED } \\
\text { OMB No. 0704-0188 }\end{array}$ \\
\hline
\end{tabular}

Public reporting burden for this collection of information is estimated to average 1 hour per response, including the time for reviewing instructions, searchiilg existing data sources, gathering and maintaining the data needed, and completing and reviewing the collection of information. Send comments regarding this burden estimate or any other aspect of this collection of information, including suggestions for reducing this burden to Washington Headquarters Services, Directorate for Information Operations and Reports, 1215 Jefferson Davis Highway, Suite 1204, Arlington, VA 22202-4302 and to the Office of Management and Budget, Paperwork Reduction Project (0704-01880), Washington, DC 20503.

\begin{tabular}{|c|c|c|c|}
\hline $\begin{array}{l}\text { 1. AGENCY USE ONLY } \\
\text { (Leave Blank) }\end{array}$ & $\begin{array}{l}\text { 2. REPORT DATE } \\
\text { August } 1993\end{array}$ & $\begin{array}{l}\text { 3. REPORT TYPE ANI } \\
\text { Preliminary site visit }\end{array}$ & $\begin{array}{l}\text { ATES COVERED } \\
\text { complete assessment. }\end{array}$ \\
\hline \multicolumn{3}{|c|}{$\begin{array}{l}\text { 4. TITLE AND SUBTITLE Preliminary Assessment Report for } \\
\text { Wayland Army National Guard Armory (Former Boston Defense Area Nike } \\
\text { Battery 73). Installation 23295, Wayland. Massachusetts }\end{array}$} & \multirow{2}{*}{$\begin{array}{l}\text { 5. FUNDING NUMBERS } \\
\text { MIPR-3788 } \\
\text { MIPR-4188 }\end{array}$} \\
\hline \multicolumn{3}{|c|}{$\begin{array}{l}\text { 6. AUTHOR(S) } \\
\text { Rebecca Haffenden: Sam Flaim: Michael Krokosz }\end{array}$} & \\
\hline \multicolumn{3}{|c|}{$\begin{array}{l}\text { 7. PERFORMING ORGANIZATION NAME(S) AND ADDRESS(ES) } \\
\text { Candace. M. Rose } \\
\text { Argonne National Laboratory } \\
9700 \text { South Cass Avenue } \\
\text { Argonne, IL } 60439\end{array}$} & $\begin{array}{l}\text { 8. PERFORMING } \\
\text { ORGANIZATION } \\
\text { REPORT NUMBER } \\
\quad \text { None }\end{array}$ \\
\hline \multicolumn{3}{|l|}{ 9. SPONSORING/MONIT } & $\begin{array}{l}\text { 10. SPONSORING/ } \\
\text { MONITORING AGENCY } \\
\text { REPORT NUMBER } \\
\text { IR-CR-9308] }\end{array}$ \\
\hline
\end{tabular}

11. SUPPLEMENTARY NOTES

None.

\begin{tabular}{|c|c|}
\hline $\begin{array}{l}\text { 12a. DISTRIBUTHQN/AV ATKABIITTYY } \\
\text { Diskribution is togovernment agenkies only. } \\
\text { Outside requests myst be made to the Ndtional duard Burgau, Army } \\
\text { Directorte. }\end{array}$ & $\begin{array}{l}\text { 12b. DISTRIBUTION } \\
\text { CODE }\end{array}$ \\
\hline
\end{tabular}

\section{ABSTRACT (MAXIMUM 200 WORDS)}

This report addresses the information necessary to complete the PA.

14. SUBJECT TERMS

15. NUMBER OF PAGES

PA-48

16. PRICE CODE

17. SECURITY

CLASSIFICATION OF REPORT

Unclassified
18. SECURITY CLASSIFICATION OF THIS REPORT

Unclassified
19. SECURITY

CLASSIFICATION OF ABSTRACT

Unclassified
20. LIMITATION OF

ABSTRACT

Unlimited 


\section{Contents}

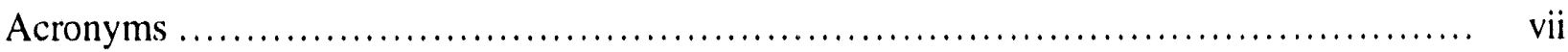

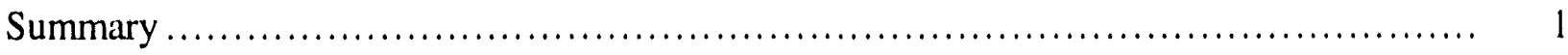

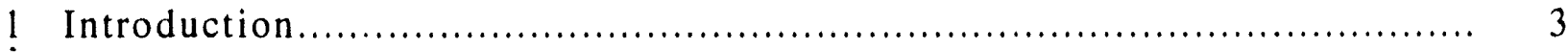

1.1 Authority for the Preliminary Assessment $\ldots \ldots \ldots \ldots \ldots \ldots \ldots \ldots \ldots \ldots \ldots \ldots \ldots$

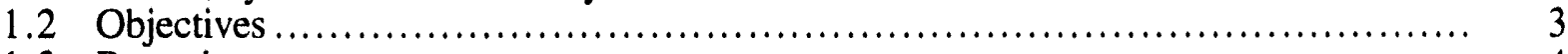

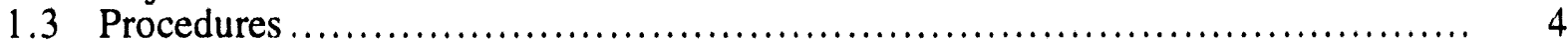

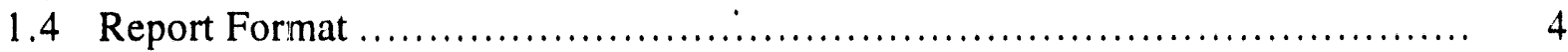

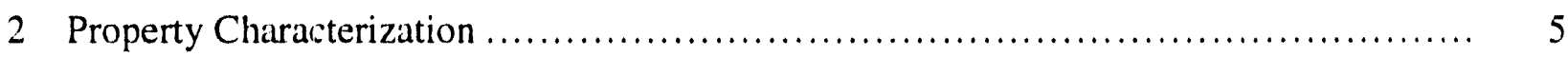

2.1 General Property Information.......................................... 5

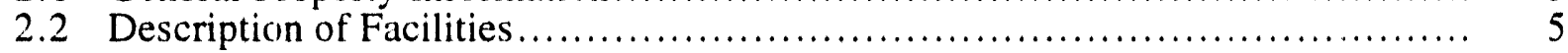

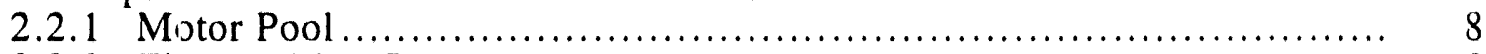

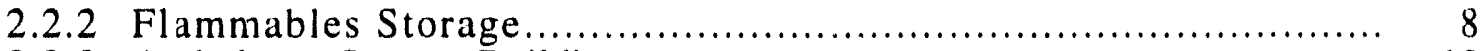

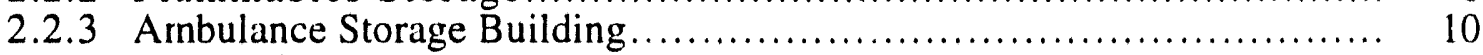

2.2.4 Armory Building ...................................................... 10

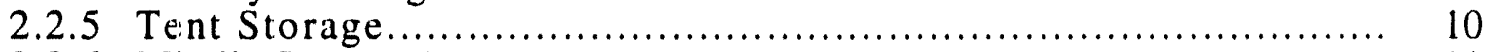

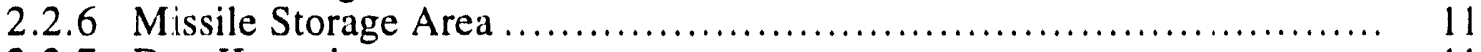

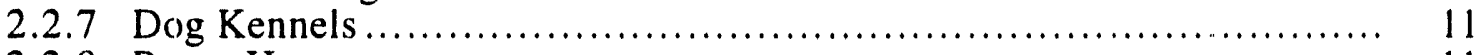

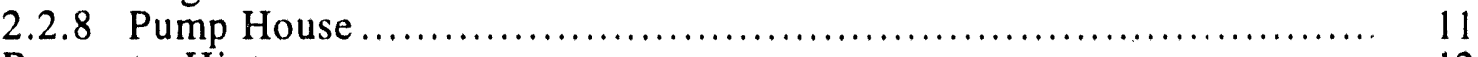

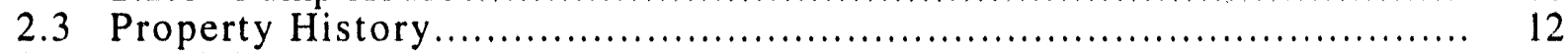

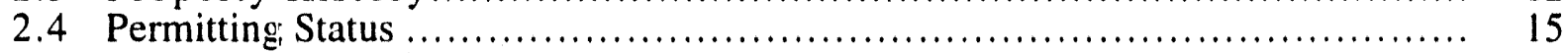

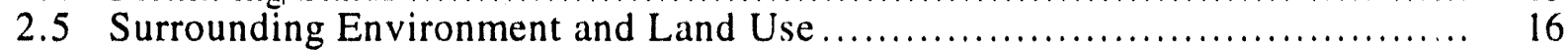

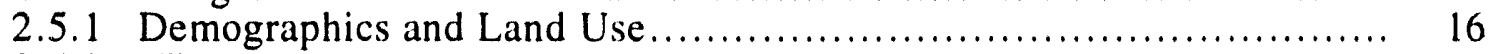

2.5 .2 Climate .............................................................. 16

2.5.3 Surface Water and Physiography ..................................... 16

2.5.4 Groundwater and Hydrogeology .................................... 19

2.5.5 Sensitive Environments.......................................... 23

3 Environmientally Significant Operations ..................................... 25

3.1 Abandoned Concrete Underground Storage Tank near the Dog Kennels ......... 25

3.2 Soil Contamination ........................................................ 25

3.3 Hydraulic Pumps for Magazine Elevators and Doors .......................... 27

4 Known and Suspected Releases ........................................... 28

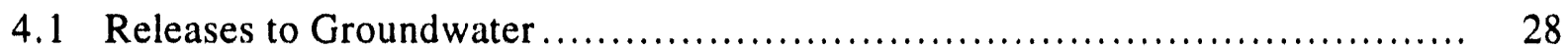

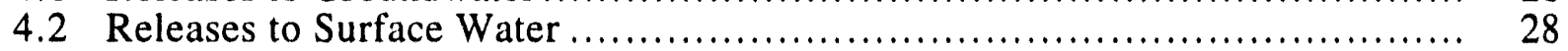

4.3 Releases to Soil .......................................................... 29

4.4 Releases to Air .............................................................. 29

4.5 Other Releases ............................................................ 29

5 Human and Environmental Receptors..................................... 30

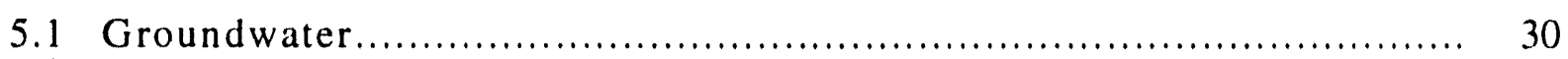

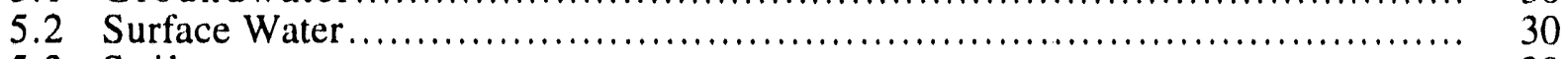

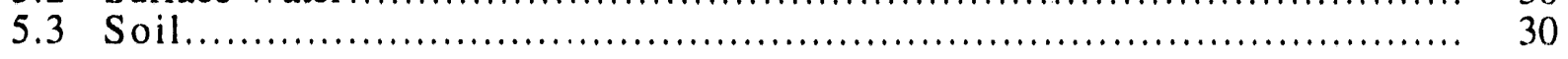




\section{Contents (Cont.)}

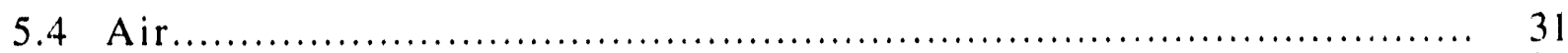

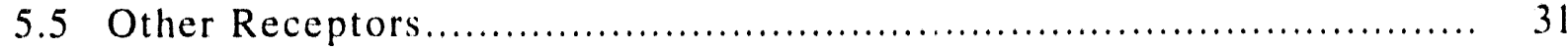

6 Preliminary Assessment Findings and Conclusions ............................. 32

6.1 Summary of Preliminary Assessment Findings ............................. 32

6.2 Recommendations for Further Action ..................................... 32

7 Sources of Information ........................................................ 34

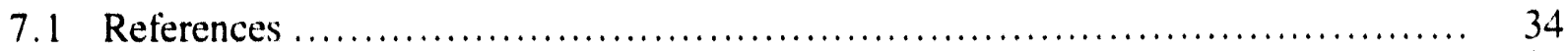

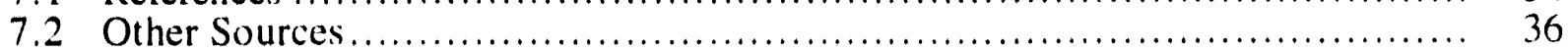

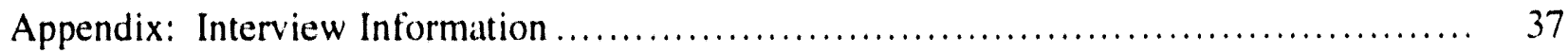

\section{Table}

1 Identifying Information for Wayland ARNG Armory ............................ 7

\section{Figures}

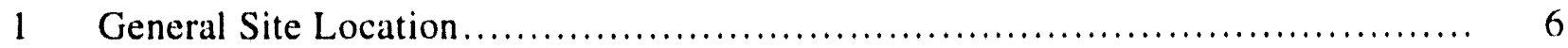

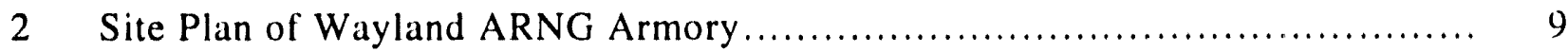

3 Surface Water around Wayland ARNG Armory $\ldots \ldots \ldots \ldots \ldots \ldots \ldots \ldots \ldots \ldots \ldots, 18$

4 Municipal Drinking Water Sources around Wayland ARNG Armory .................. 22

5 Environmentally Significant Operations at Wayland ARNG Armory................. 26 


\section{Acronyms}

AEC

ARNG

CERCLA

EPA

ESO

FISP

gpm

IRFNA

IRP

MAARNG

MSL

PA

PCB

TDS

UDMH

USGS

UST
Atomic Energy Commission

Army National Guard

Comprehensive Environmental Response, Compensation, and Liability Act

U.S. Environmental Protection Agency

environmentally significant operation

Facility Inventory and Stationing Plan

gallons per minute

inhibited red fuming nitric acid

Installation Restoration Program

Massachusetts Army National Guard

median sea level

preliminary assessment

polychlorinated biphenyl

total dissolved solids

unsymmetrical dimethylhydrazine

U.S. Geological Survey

underground storage tank 


\title{
Preliminary Assessment Report for \\ Wayland Army National Guard Armory \\ (Former Boston Defense Area Nike Battery 73), \\ Installation 23295, \\ Wayland, Massachusetts
}

\begin{abstract}
Summary
This report presents the results of the preliminary assessment (PA) conducted by Argonne National Laboratory at the Massachusetts Army National Guard property near Wayland, Massachusetts. Preliminary assessments of federal facilities are being conducted to compile the information necessary for completing preremedial activities and to provide a basis for establishing corrective actions in response to releases of hazardous substances. The principal objective of the PA is to characterize the site accurately and determine the need for further action by examining site activities, quantities of hazardous substances present, and potential pathways by which contamination could affect public health and the environment. This PA satisfies, for the Wayland Army National Guard Armory property, Phase I of the Department of Defense Installation Restoration Program.
\end{abstract}

The Wayland Army National Guard Armory (Wayland Armory) is a 29.2-acre site located in the eastern portion of Massachusetts, in Middlesex County, approximately 18 mi west of Boston. The Wayland Armory was a launch area for Nike Battery 73. The buildings and improvements included in this PA are nine buildings, two launcher storage areas, and parking areas. The environmentally significant operations associated with the property are (1) an abandoned concrete underground storage tank near the dog kennels (L-18); (2) stained soil outside the current and abandoned flammable storage buildings and fuel oil stains on the floor of the former generator building (L-3), which run to floor conduits and thereby to the soil beneath the building; and (3) the hydraulic pumps to operate the magazine elevator and door lifts, which may have been abandoned without draining the hydraulic fluids.

The review of both historical and current practices at the property indicated that the Wayland Armory property poses a low level of risk to human health or the environment. However, Argonne's reviewers noted the following areas of concern:

- Stains to the soil outside the current flammable storage building (L-9) and outside the abandoned flammable storage building (unnumbered). 
- Three old transformers located in the current ambulance supply building (L-3).

- A 55-gal rusting drum containing an unknown liquid (with an open bung), which is sitting by the door of the current ambulance supply building (L-3).

- A metal plate in the ground covering a concrete underground storage tank with liquid visible through the opening to within $2 \mathrm{ft}$ of ground level, located to the northeast of the dog kennel (L-18).

- A small transformer and an empty 1,000-gal aboveground tank located in the water pump building (L-10).

- The possible abandonment, without draining, of the hydraulic pumps for the magazine elevators and doors, creating the possibility of hydraulic fluid leaks in the magazine.

The historical overview of Nike battery operations (McMaster 1984), suggests other areas of concern that could not be verified from records or visual inspection. These include the following:

- An acid neutralization pit immediately west of the former warheading building (L-11), with an outfall combining with stormwater discharge at the northern boundary of the site.

- Sumps used for disposal of liquid wastes in or near the former generator building (L-3), the former warheading building (L-11), and the former missile maintenance building (L-5).

- Fueling or defueling releases of liquid propellants or JP-4 (jet fuel) on or near the concrete pad and concave/convex formations located immediately northeast of the former warheading building (L-11). 


\section{Introduction}

This document is a report of the preliminary assessment (PA) conducted by Argonne National Laboratory at the Massachusetts Army National Guard (MAARNG) property known as Wayland Army National Guard Armory, located in Wayland, Massachusetts.

\subsection{Authority for the Preliminary Assessment}

The National Guard Bureau, Army Directorate, has engaged Argonne to perform PAs of selected state Army National Guard (ARNG) properties. These assessments are being done in a manner consistent with both the Department of Defense Installation Restoration Program (IRP) and the U.S. Environmental Protection Agency's (EPA's) Potential Hazardous Waste Site Preliminary Assessment Guidance. Preliminary assessments of state ARNG properties are conducted under the authority and direction of the IRP; the Comprehensive Environmental Response, Compensation, and Liability Act (CERCLA or, more commonly, Superfund); and the Superfund Amendments and Reauthorization Act of 1986 (Public Law 99-499).

\subsection{Objectives}

This PA report is based on existing information from the MAARNG records that were made available to Argonne investigators and from other sources. Although this PA effort did not extend to the generation of new data, it nonetheless identifies areas where existing data are incomplete, unreliable, or ambiguous and recommends ways to address such shortcomings.

The objectives of the PA are to satisfy Phase I of the IRP and to

- Identify and characterize the environmentally significant operations (ESOs),

- Identify property areas or ESOs that may raquire a site investigation,

- Identify ESOs or areas of environmental contamination that may reghire immediate removal, 
- Identify properties for which no further action is needed, and

- Provide information sufficient to prescore the site with the EPA's PA Scoresheets (EPA 1991).

\subsection{Procedures}

The PA began with a review of MAARNG files located at MAARNG Headquarters at Camp Curtis Guild, Reading, Massachusetts, on April 19, 1993. A site visit was conducted on April 21, 1993, to obtain additional information through direct observation and interviews with personnel familiar with the property and its operations. In addition, interviews were conducted with personnel from the Sudbury Water District, Lincoln Engineering Department, Concord Town Offices, and Weston Town Engineering and Water Department. Other relevant information was obtained on April 23, 1993, in the Boston, Massachusetts, offices of the Massachusetts Department of Environmental Management, Office of Water Resources; the Massachusetts Division of Fisheries and Wildlife; and the Massachusetts Department of Environmental Protection, Office of Planning and Program Management, Division of Water Supply. Additional information was obtained through telephone interviews with the U.S. Park Service, Pantry Brook Wildlife Management Area Offices, and Great Meadows National Wildlife Refuge Offices.

\subsection{Report Format}

This PA report presents a summary and evaluation of the data relevant to the PA for this property. Section 2 describes the property and its surrounding environment and land use. Section 3 identifies and characterizes the ESOs at the site. Section 4 discusses known and suspected releases to the environment, and Section 5 discusses potential human and environmental receptors for such releases. Section 6 summarizes the findings and conclusions, discusses the quality and reliability of the supporting information, identifies areas requiring further action, and (as appropriate) suggests how such actions ca 1 be accomplished. Section 7 lists pertinent materials reviewed. The Appendix contains interview information and lists the Argonne investigators. 


\section{Property Characterization}

\subsection{General Property Information}

The Wayland Armory is a 29.2-acre site located approximately 18 mi west of Boston, in Wayland, Massachusetts, in Middlesex County. The Wayland Armory is located in the Sudbury River drainage basin approximately $0.5 \mathrm{mi}$ from the borders of the Great Meadows National Wildlife Refuge and the Pantry Brook State Wildlife Refuge. This PA discusses nine buildings typical of Nike installations, including two missile launcher magazines.

Drinking water for the site is obtained from the Wayland Water Department. Electric service is obtained from a commercial public utility. The site has an on-site septic system for the treatment of sanitary waste. When the site was used as a Nike battery site, electrical power was generated on-site in the former generator building (L-3) by using generators fired with fuel oil, fied from a 3,000-gal underground storage tank (UST). The UST was removed in 1991. Drinking water was obtained from a 225-ft-deep on-site artesian well, pumped to a 20,000-gal water tank. Although the pump house, water tank, and well have not been dismantled, the pipes leading to the pump house and the Nike silos were capped in approximately 1975 (USAEHA 1987). Figure 1 shows the general location of the property, and Table 1 lists pertinent information about it.

There are currently four full-time staff from Company F (Medical), 114th Main Support Battalion at the site during the day, five days each week. During weekend drills, approximately 90 MAARNG members occupy the site. During the operation of the Nike facility, approximately 20-25 people occupied the facility during the day and 10-15 at night, according to a former guided-missile mechanical repairman for the site.

\subsection{Description of Facilities}

The Wayland property is currently a National Guard training facility. Units or teams are trained in medical response activities. The teams are then assigned to other MAARNG units for weekend drills in the field. Staff at this site train medical personnel and, on drilling weekends, dispense medical equipment, trucks, and tents to the assigned medical team. Light operator 


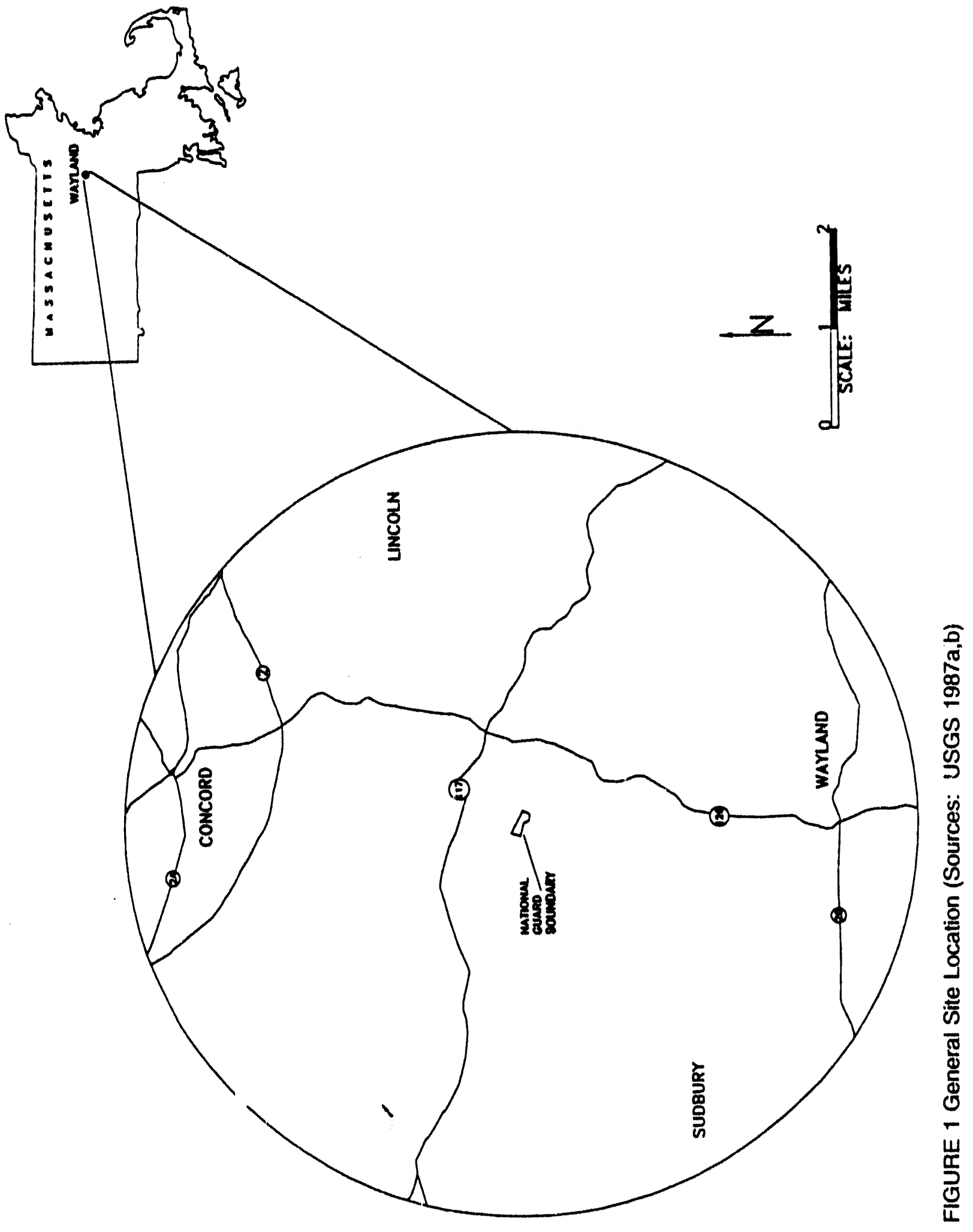


TABLE 1 Identifying Information for Wayland ARNG Armory

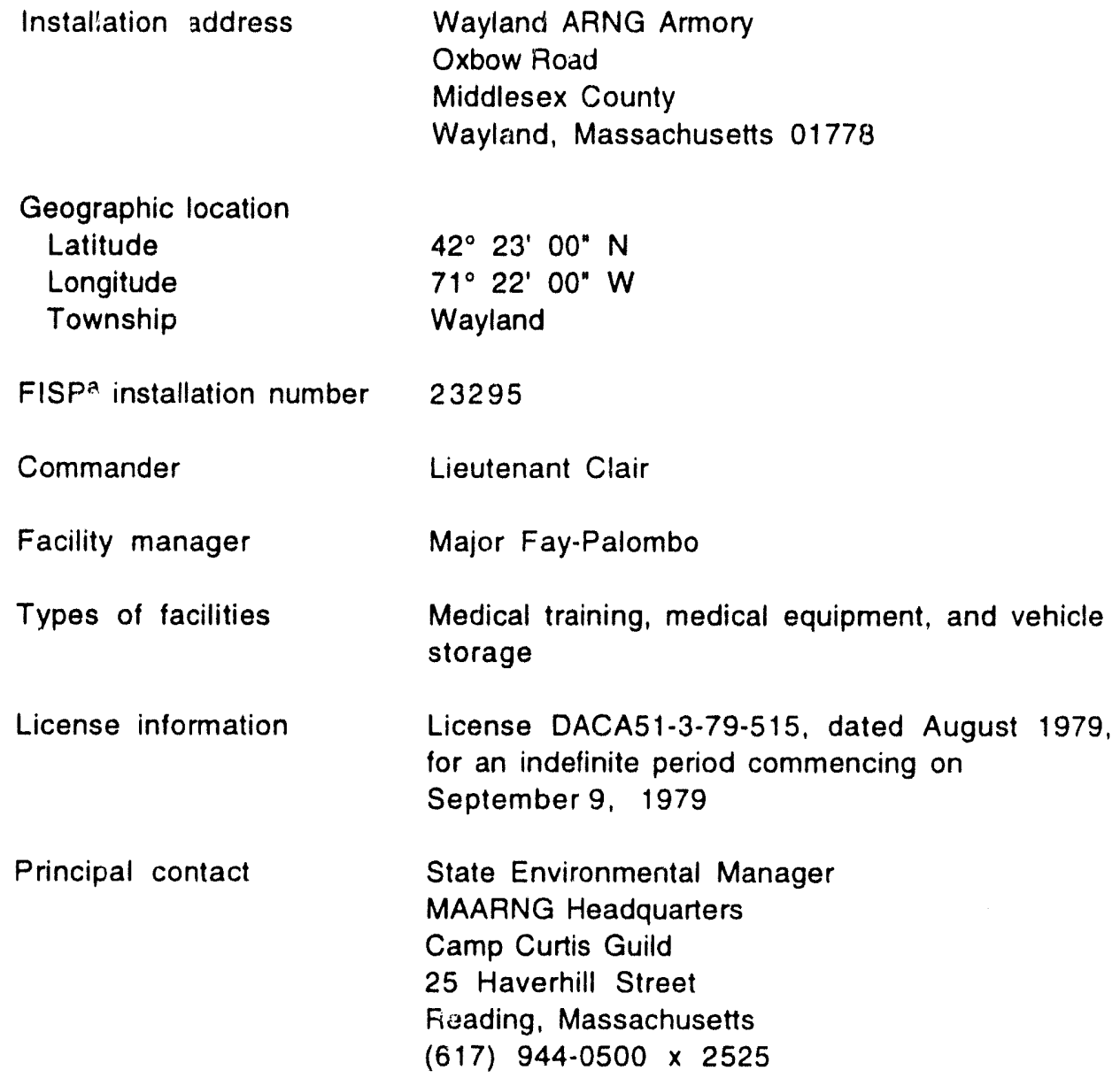

a Facility Inventory and Stationing Plan.

maintenance is performed on the vehicles, including adding oil or other fluids and checking batteries. Any substantial vehicle maintenance is performed at Operational Maintenance Shop 7 in Framingham, Massachusetts.

The former barracks (Building L-1) is the major improvement and contains the kitchen, dıning hall, classroom, supply storage, bath facilities, and administrative offices. The former missile assembly building (L-5) is used as the motor pool and for storage. Building L-3, once the Nike generator building, is used to store ambulance equipment. Building $\mathrm{L}-11$, the former warheading building, is used to store tents and other equipment. Building L-9 is currently used to store flainmables. Building L-10, the former pump house, is used for storage. An unnumbered, garage-like building between L-5 and L-3 is also used for storage. Anothar unnumbered building 
to the east of the water tank is abandoned but was apparently used for flammables storage. Building L-18, the former dog kennel, is abandoned. Buildings L-6 and L-7 are the abandoned Nike missile launcher magazines. Figure 2 shows the facilities located at the site.

\subsubsection{Motor Pool (Former Missile Assembly Building) (L-5)}

The motor pool building contains vehicle maintenance supplies, including oil, battery water, antifreeze, and welding equipment. Only driver maintenance (adding oil or antifreeze) currently takes place at this site. Poor housekeeping, rather than contaminant releases, appears to be a problem in this building. This building was once the Nike missile assembly building. Missiles were wheeled into the building for regular maintenance activities.

Building L-5 was once heated with a No. 2 fuel oil boiler. The building has since been converted to natural gas heat, and the 1,000-gal aboveground tank to the southwest was removed in 1991. The tank was pumped out to the maximum extent possible, and fuel and associated bottom sludges were removed and disposed of in accordance with Massachusetts regulations. No evidence of spills, leaks, or distressed vegetation is found at the prior location of the tank.

\subsubsection{Flammables Storage (L-9)}

Flammables, acids, and compressed gases are stored in the small shed designated Building L-9. The shed sits on a concrete pad with no lip. Some spillage, approximately $1 \mathrm{ft} \times 1 \mathrm{ft}$ in size, to the concrete step and the soil outside the door is evident. On some site plan drawings, Building L-9 is shown as liquid propellant storage. The Ajax missiles deployed at this site in 1955-1959 did have liquid propellants, but the Hercules missiles deployed in 1959-1974 used solid propellant, and no liquid propellants were present at that time. No information is available concerning the usage of this building before 1965 other than the notations on the site plan maps. An unnumbered building located to the north of Building L-9, to the west of Building L-10, and to the east of Building L-3 was also a flammables storage building. This storage facility also shows signs of leakage or spillage measuring approximately $2 \mathrm{ft} \times 3 \mathrm{ft}$ in front of the door. 


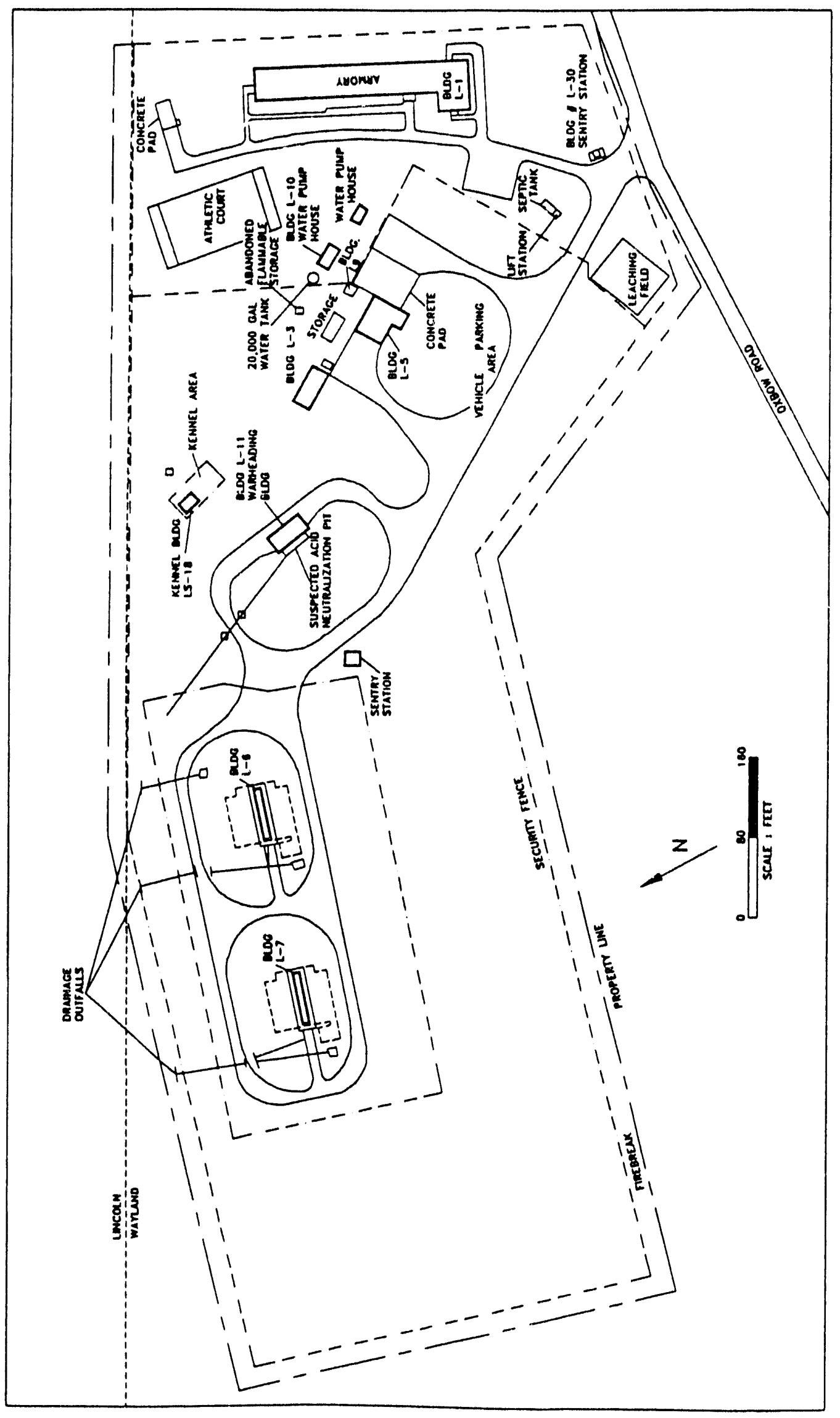

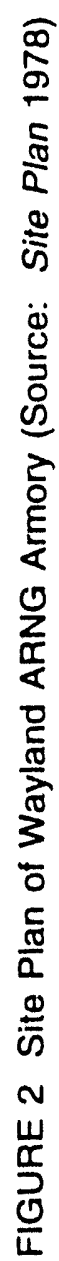




\subsubsection{Ambulance Storage Building (Former Generator Building) (L-3)}

Building L-3 once housed three large electric generators. The generators were fired with fuel oil, fed by a 3,000-gal UST located to the north of the building. This large tank fed a smaller 200-gal aboveground tank located inside the easternmost room of the building. The generators were removed in 1974 when the Nike installation was decommissioned. Three older transformers are still in the building; no evidence of leakage exists.

The 3,000-gal UST was removed in 1991. The tank was pumped to the maximum extent possible, and the sludges were removed and discarded in accordance with Massachusetts regulations. The tank was cleaned and purged of any vapors. The tank was then excavated and removed from the ground. According to Massachusetts regulations, the local fire chief was present and confirmed from a visual inspection that no leakage was seen. The contractor then backfilled and compacted the site and transported the tank off-site for disposal. No soil samples were taken.

\subsubsection{Armory Building (Former Barracks) (L-1)}

Building L-1 contains no ESOs. The building at one time had a No. 2 fuel oil boiler for heat. The building has since been converted to natural gas heat, and the 2,000-gal UST was removed in 1991. The tank was excavated, cleaned, and disposed of according to Massachusetts regulations. No documentation that soil samples were taken exists.

\subsubsection{Tent Storage (Former Warheading Building) (L-11)}

Building L-11 is surrounded by earthen berms. It is currently used for tent storage, but it was once the warhead maintenance building and was used by trained teams to remove and maintain the missile warheads. Certain of the Hercules warheads were nuclear. Outside the west door of the building is a concrete pad with raised convex and concave formations. A storm drain opening is evident under one of the concrete slabs, and a water faucet is set above. These formations were not used in 1966-1974, when Hercules missiles were located at the site (information from a former guided-missile mechanical repairman). The formations may have been used in fueling or defueling of Ajax missiles in 1955-1959. On certain site plan maps, an acid neutralization pit is shown immediately to the west of Building L-11, with a connecting pipe originating inside the building. 


\subsubsection{Missile Storage Area (L-6 and L-7)}

The concrete underground missile magazines are abandoned. The doors are set into macadam with plants growing through the large cracks covering the surface. The doors have rusted or are locked. The magazines may have been abandoned without draining the hydraulic elevator and door lift pumps. Although it is rusty and peeling, the stairway down to the lower magazine area showed no evidence of water accumulation. Past observation and analysis of rainwater accumulated in the magazines showed no apparent signs of contamination (USAEHA 1987). During operation, rainwater that collected in the underground chambers was pumped out into a swale, which also carried the surface runoff to an off-site outfall located at the northern boundary of the site (USAEHA 1987).

\subsubsection{Dog Kennels (L-18)}

When the site was an active Nike battery, guard dogs were kept in Building L-18 and the surrounding pens. A small, open-sided shed with a water supply faucet was possibly used for washing the dogs, according to a former guided-missile mechanical repairman for the site. Located approximately 25 yards to the northeast of the kennel building is a metal plate set into the grass. Under this plate is a concrete UST nearly full of liquid. Although on some site plans the open-sided shed with water service is shown as an acid storage area, this area was not used for acid disposal in 1966-1974 (information from former guided-missile mechanical repairman), probably because of the phaseout of lead-acid batteries in the later Hercules missiles. This area may have been used for acid storage prior to 1966 (hence the water supply). However, no information is available to confirm this usage.

\subsubsection{Pump House (L-10)}

The pump is still present inside Building L-10, as is a large aboveground tank. However, the building is currently used only for storage. An old Westinghouse transformer is on the south wall. No evidence of leakage from the transformer exists. 


\subsection{Property History}

The Wayland Armory was acquired by the U.S. Army in 1954 for the national Nike defense program. Prior to purchase, the area consisted of rural farm land with a few houses and an undeveloped road system. The Launcher Area, Nike Boston 73, was constructed in 1955 as part of the antiaircraft system for defense of the Greater Boston area. The property was transferred to the National Guard in approximately 1962 for use as a Nike battery. Interviews with a former guided-missile mechanical repairman who was deployed to the Wayland Armory in 1966-1974 provided invaluable information concerning operations during that period. All subsequent references to information concerning 1966-1974 in this PA are attributable to interviews with this repairman. However, for operations prior to 1966, a historical overview (McMaster et al. 1984) provides the only available information. In 1974-1985, the National Guard operated the facility as a maintenance facility. In 1985-1988, the same former guided-missile mechanical repairman returned under the 726th Maintenance Battalion, B Company. The property is currently governed by license DACA51-3-79-515, effective September 9, 1979, and extending for an indefinite period.

Unless otherwise indicated, the following historical description of operations at Nike facilities is taken from McMaster et al. (1984). The Wayland Ärmory was a Nike launching battery deploying Ajax missiles in 1955-1958. In 1959, the facility was converted to the Nike Hercules and remained so until its transfer to the National Guard in 1962. The National Guard operated the facility until August 1974 (information from former guided-missile mechanical repairman).

Contaminants of concern for the Ajax missile included liquid fuel, unsymmetrical dimethylhydrazine (ULMH), aniline, and inhibited red fuming nitric acid (IRFNA). However, in general, these materials were handled in a way that generated minimal spillage or ground contamination because of concerns for personnel safety. The Hercules missiles used solid fuel, thus eliminating the liquid fueling procedures. The solid fuel was a cast propellant, with the grain being an integral part of the motor. Early Hercules also used three liquid electrolyte batteries per missile, but these were later replaced by nickel-cadmium batteries, whi th did not require fluid changing.

The typical Nike battery consisted of two main operating areas. The battery control area contained the electronic equipment for target tracking, missile guidance, and fire control. The launch area contained the facilities and equipment required to assemble, test, and maintain the 
missiles and associated launchers. Motor pools, generator buildings, guard dog kennels, and other support facilities were also generally included in this area. However, no vehicle maintenance or refueling was performed at this site in 1966-1974.

General operational procedures used at Nike sites were consistent, although specifics of material handling and disposal varied considerably for individual batteries. The most common liquids discarded on-site were solvents used in maintenance operations. These solvents were routinely dumped into sumps where they soaked into the ground. In isolated incidents, containerized disposal was reported. From 1966 to 1974, wastes were containerized in 55-gal drums and sent to Ft. Devens for proper disposal.

Generator buildings were generally equipped with a sump that was routinely used for the disposal of the oil, solvents, and paints used in equipment maintenance. These sumps were typically excavated pits $\left(1-2 \mathrm{~m}^{3}\right)$ backfilled with gravel, where liquids were simply dumped and allowed to soak into the ground. Liquids dumped reportedly included sizable quantities of diesel fuel, because the generator design made spillage during filling likely. From 1966 to 1974. no known disposal to sumps occurred. Wastes were containerized in 55-gal drums and sent to Ft. Devens for proper disposal.

Operations involving toxic and hazardous materials included fueling, defueling, and addition/changeout of missile constituents; support equipment maintenance and repair; and material handling and storage. When larger quantities were used for overall cleaning, residues were washed into the sump or onto the ground surface. Waste oil was frequently dumped into a sump, although drumming for turn-in was also commonly practiced. From 1966 to 1974, Hercules missiles, which had no liquid fueling or defueling operations, were deployed at this site. In 1966-1974, waste oils were containerized in 55-gal drums and sent to Ft. Devens for proper disposal.

Warhead placement, also a part of the initial assembly, was performed in the warheading building. Additional aspects of assembly involved pressurization, addition of hydraulic fluids, and connection of the electrical/electronic cable systems for integration with 1 : sunch Control. Assembly operations presented minimal potential for contaminant generation, although some solvents were used for cleaning electrical contacts and assembly points. Some spillage of hydraulic fluids occurred during the initial filling process. 
Disposal of hydraulic fluid from missiles depended on the individual battery. Sometimes the fluid was flushed into drums for turn-in, flushed into a ground sump, or used for weed control around buildings and fences. Most of the hydraulic fluid used was contained in missile launchers. This fluid was changed annually or more frequently. Quantities of hydraulic fluid dumped reportedly ranged from 1,900 to 3,785 lb/yr. In 1966-1974, hydraulic fluids from change-outs were drumıned and taken to Ft. Devens for proper disposal. In addition, hydraulic fluid spills in the magazines and at launch pads were common, both from routine maintenance and rupture of lines. Leakage of fluid from elevator hydraulics could produce a considerable volume for disposal to the sump. Hydraulic system "blow-outs" occurring during operation of any hydraulic equipment would cause instant release of tluid (Law Engineering Testing Company 1986). These spills would run to floor drains that routed any liquid to a sump normally located below the missile elevator shaft. These sumps were usually equipped with level-controlled pumps that transferred accumulated liquid to surface drainageways and thereby to the soil. This is the case at the Wayland site. Once released either on the ground or underground, petroleum products, attenuated somewhat by sorption on soil, move downward until either a restrictive horizon or the water table is intercepted. The portion that reaches the groundwater is partitioned into a free product that forms on top of the water and spreads laterally and a dissolved or emulsified product in the aquifer.

Laurcher maintenance/repair conducted in the launch area generally involved the use of various solvents, cleaners, paints, and thinners, such as trichloroethane, trichlorvethylene, toluene, carbon tetrachloride, acetone, and alcohol. These chemiculs were used for a variety of functions, including cluaning of contacting parts, cleaning of grease spills or stains, and overall cleaning in preparation for painting. The use of carbon tetrachloride and trichloroethylene was gradually phased out during the Hercules era, and PD-680 or Stoddard II solvents were introduced. These solvents are nonreactive compounds in the environment; they are not subject to photolytic, oxidative, hydrolytic, or biologic reactions to a significant degree. The volatility of the compounds is such that a portion of the solvent would have evaporated during use. Waste solvents and cleaners were typically poured into a ground sump where they soaked into the ground, but they were sometimes drummed for turn-in. In the magazine, waste materials - solvents, paints, and hydraulic fluid - were often washed to the magazine sump located at the bottom of the elevator shaft and pumped to surface drainageways and thereby to the soil. Carbon tetrachloride was used as a multipurpose solvent at the Wayland Armory, according to a former guided-missile mechanical tepairman. Carbon tetrachloride was gradually replaced, in turn, by trichloroethylene and trichloroethane. In 1966-1974, solvent wastes were drummed and taken to Ft. Devens for proper disposal. 
The physical and transport data for chlorinated organic solvents indicate that solvents poured onto the ground will experience some retardation relative to percolating water because of adsorption by soil organic matter. The lack of hydrolytic reactivity and the tendency to be sorbed suggest that once introduced into groundwater, the chlorinated solvents can be persistent, particularly when groundwater movement is slow. No analysis of the groundwater from this site has been done.

Lead battery electrolyte, often after acid neutralization, was dumped into a sump or otherwise discarded on-site. Such disposal would result in the release of lead to soils and potentially to surface watter and groundwater. Normally, lead is immobilized in soil, its very low solubility restricting downward movement into groundwater. The disposal of large quantities of unneutralized electrolyte at the same location each month would enhance the possibility of contaminating groundwater. Battery electrolyte was reportedly discarded in the warhead maintenance area drainage system. Modest amounts of lead may have been introduced as a result of this operation. However, other sources of lead, such as paint, were likely of much greater magnitude. Sulfates and nitrates in the warhead maintenance area would be insignificant in the concentrations at which they would occur (Law Engineering Testing Company 1986). An acid neutralization pit immediately to the west of the warheading building $(L-11)$ and a corresponding drainage system running to the north are shown on certain site plans for this ficility (Layout and Grading Plan 1958). No information is available concerning the amount or nature of the acid placed in such a system. In 1966-1974, no acid neutralization was noted, probably because the later Hercules missiles used nickel-cadmium batteries, rather than lead-acid batteries.

The maintenance of Nike Hercules nuclear warheads required periodic wipe tests to establish the absence of radioactive leaks. The wipes were disposed of in facilities licensed by the U.S. Atomic Energy Commission (AEC). Often these facilities consisted of a lead-lined drum kept in a secure location. Defective electron tubes containing radioactive isotopes were also kept in this drum. The storage facilities were monitored for radioactivity in compliance with the terms of the AEC license. At the time of deactivation, the storage facilities were reportedly closed and removed in accordance with AEC requirements. No instances of release of radioactive materials into the environment were reported.

\subsection{Permitting Status}

The Wayland Armory holds no environmental permits. 


\subsection{Surrounding Environment and Land Use}

\subsubsection{Demographics and Land Use}

The area surrounding the Wayland site is now heavily populated. The facility lies in the northern portion of the town of Wayland (population 12,190). To the east are the town of Lincoln (population 7,710) and the town of Weston (population 10,700), to the west is the town of Sudbury (population 14,140), and to the north is the town of Concord (population 16,470). However, the area immediately surrounding the site, within approximately 2 mi, includes a large section of the Great Meadows National Wildlife Refuge, the Pantry Brook Statc Wildlife Management Area, the Sudbury River basin, and other unpopulated areas. Two large townhouse projects lie immediately north of the site, Furrar Pond Village and Lincoln Ridge at Farrar Pond (each consisting of approximately 80 townhouse units). Otherwise, the area consists of single-family homes. A new development is currently being constructed immediately west of the site.

\subsubsection{Climate}

Wayland is in the central Massachusetts climatological division, which covers more than $40 \%$ of the state and has a humid climate characteristic of the North Temperate Zone. The mean annual temperature is $49.6^{\circ} \mathrm{F}$, with a monthly mean of $25.6^{\circ} \mathrm{F}$ in January and $73 . !^{\circ} \mathrm{F}$ in July (NOAA). The annual average precipitation is $45.34 \mathrm{in.,}$ with the heaviest accumulations in January (12.97 in.), August (15.69 in.), and September (13.61 in.) (Gale 1985). The prevailing wind, on a yearly basis, comes from a westerly direction. Although the Boston area is affected by the on-shore winds blowing from the ocean, these winds are felt rarely as far inland as Wayland.

\subsubsection{Surface Water and Phyalography}

Wayland is Ic *..ed entirely within the New England Upland section of the New England physiographic province (Harrison et al. 1983) and displays low relief. The general topography of the area is gently rolling hills interspersed with a few rugged terrain features, reflecting a northeastern basal alignment that decreases in elevation eastward. The land surfaces are marked by numerous remnunt glacial deposits forming hummocks sepurated by streams and marshes. 
Surface water is abundant at the site, which is located on a freshwater peninsula tormed by the Sudbury River to the west. Farrar Pond to the north, and an unnamed stream tributary to the Sudbury River to the south. Within a 4-mi radius of the site, 5,(20) acres are characterized on the USGS topographic maps as submerged marsh, marsh, or swamp. Elevations in the area range from $100 \mathrm{ft}$ to $300 \mathrm{ft}$ above median sea level (MSL). Low-lying areas with elevations between $115 \mathrm{ft}$ and $130 \mathrm{ft}$ above MSL occur as marshes and swamps between the low, hummocky knolls. The Sudbury River begins in wetlands in Westborough before flowing eastward to Ashland, and then uorthward and northeastward to its confluence with the Assabet River, creating the Concord River. In its lower reaches, the Sudbury River has a lower stream gradient than the Assabet River. The lowest stream gradient, above $1 \mathrm{ft} / \mathrm{mi}$, occurs along an approximately $12-\mathrm{mi}$ reach of the Sudbury River that flows through Great Meadows National Wildlife Refuge in the towns of Sudbury, Wayland, Lincoln, and Concord. Figure 3 shows the surfice water features within a 4-mi radius of the site.

The 29.2-acre site is located on the topographically highest point in the immediate area between Farrar Pond and the Sudbury River. Elevations on the site range from $182 \mathrm{ft} 10201 \mathrm{ft}$ above MSL. The highest elevations correspond with the man-made berms on either side of the warheading building (L-11). A grading plan (Crading Plan 1960) indicates the discharge details of the site, but a visual inspection of the site could not confirm the actual existence of these underground conduits. A visual inspection did reveal the three discharge areas at the north fence. As the plan shows, runoff from the eastern berm is directed easterly to a 400 )-ft rock blanket ditch that slopes to outlets near the former generator building (L-3) or to an underground conduit that directs southerly flows to the outlets near the former generator building (L-3) or northerly to a surface grate located north of the warheading building (L-11). Easterly runoff from the western berm is directed to a 140-ft rock blanket ditch that is sloped to enter the surface grate located north of the warheading building (L-11). Westerly runoff from the western berm is directed to the roadway. A 4-in. pipe runs from the warheading buildi.ıg to an underground acid neutralization pit that, in turn, empties into the 15 -in. pipe connecting the surface grates taking in storm runoff. This 15-in. pipe runs approximately $170 \mathrm{ft}$ to a rock discharge outfill located at the northern boundary of the site.

Three underground conduits direct storm water through surface grates from the magazine tarmac to outfalls along the northern boundary of the property. The conduit farthest west has two surface grates and also receives liquids pumped from the bottom of the magazines through the sump. This conduit exits to a rock blanket apron approximately $65 \mathrm{ft}$ north of the western 


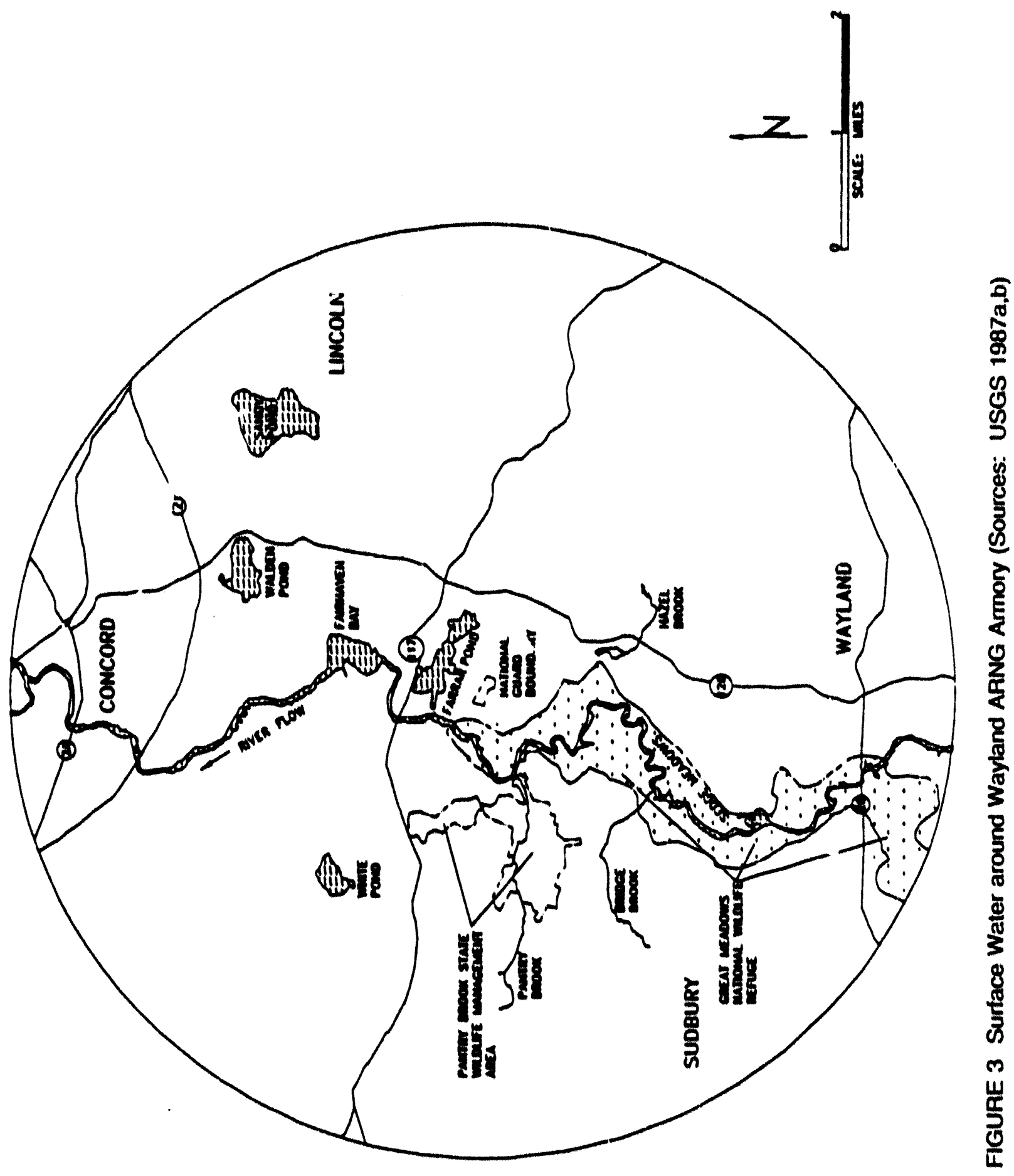


magazine. A similar conduit with two surface grates runs between the two magazines. This conduit also receives liquids pumped from the bottom of the eastern magazine and from the hatch south of the magazine. This conduit exits to a rock blanket apron approximately $65 \mathrm{ft}$ north of the eastern magazine and approximately $160 \mathrm{ft}$ east of the first conduit. A third conduit has one surface grate located between the eastern magazine and the magazine fence. This conduit also exits to a rock blanket apron at the northern boundary of the site, approximately $110 \mathrm{ft}$ east of the second outfall.

The southern and western limits of the cantonment are graded or embanked to ciivert water inward toward surface grates between and adjacent to the magazine complexes. The eastern limits are graded to divert flow off-site to the north and south.

Upon leaving the immediate area of the site and during periods of high runoff, surface water from the east side of the site discharges to the yard of a nearby residence. Runoff from the parking areas and roadways discharges to Oxbow Road, where the runoff is captured by a Wayland storm sewer grate. Runoff from the north dry sumps and the ontflow rock blankets discharges to a wooded area and possibly, in times of very high flooding, into the storm sewer system of a residential complex 400-600 ft north of the site or downgradient along erosion surfaces into Farrar Pond. Marginal runoff from western and southern portions of the site enters a new residential development to the west (which has its own storm sewer drainage system), enters the drainage system along Oxbow Road to the south, or travels along downgradient erosion pathways into the estuary associated with the Sudbury River.

\subsubsection{Groundwater and Hydrogeology}

\subsubsection{Local Geology}

The New England Upland section is composed of Pleistocene (Allegheny) glacial deposits overlying metamorphosed Precambrian to Devonian intrusive, sedimentary, and volcanic rocks. The lithologies within this section, which extend northeastward across eastern Massachusetts, are primarily high-grade metasediments and metavolcanics (metamorphosed to sillimanite grade) and intrusives (granites and granodiorites). The parent rocks of the gneisses and schists composing the metamorphic sequences have been interpreted as flysch deposits, laid down in an early to middle Paleozoic eugeosynclinal trough (Holland 1980). In general, the region can be viewed as a large subsiding area that was undergoing peripheral uplift, erosion, and volcanism. This activity 
produced a sequence of clastic material and resulted in relatively rapid deposition of clastic material.

The New England Upland section is cut by numerous northeasterly trending faults, some of which (Clinton-Newbury fault) are large-scale features. These faults all dip to the northeast and show movement from west to east. The Clinton-Newbury fault is believed to be associated with the suture zone between the African and North American lithospheric plates (Holland 1980).

The surface material overlying the metamorphosed Paleozoic and Precambrian bedrock is composed of two general categories of glacial material, till and stratified drift, each having a unique mode of origin. During the Pleistocene, movirg ice scraped up soil material and abraded bedrock. This material was spread out or heaped up by the ice or, as the ice melted, was dropped as an unsorted, heterogeneous mixture called till. The remainder was picked up by meltwater and deposited as stratified drift consisting of sorted beds of gravel, silt, and clay (Koteff 1964).

\subsubsection{Local itydrology}

The water-bearing formations of Massachusetts consist of surficial deposits of primarily glacial origin and bedrock deposits of both sedimentary and crystalline origin.

Regionally, groundwater occurs principally in unconsolidated Pleistocene glacial surface deposits. The deposits that are of hydrologic importance include unstratified drift (till), stratified drift (outwash), and glaciolacustrine, lacustrine, and marine sediments. Water yields from such deposits are variable from one location to another and depend on local characteristics. Stratified drift deposits are the best source of supply, with aquifers of this type producing as much as $1,000$ gallons per minute ( $\mathrm{gpm})$. The mineral composition of this kind of aquifer is commonly 99\% quartz and feldspar, which are chemically stable, nonreactive, and virtually insoluble in water. Water from this type of aquifer has small concentrations of dissolved solids and is soft and slightly acidic. Analyses of 697 public water supply wells in glacial drift aquifers, performed in 1984, showed that the median dissolved solids concentration was $88 \mathrm{mg} / \mathrm{L}$ and that the median hardness as calcium carbonate was $32 \mathrm{mg} / \mathrm{L}$, while the $\mathrm{pH}$ for $85 \%$ of the samples was 6.3 . Analysis of the Wayland Water Company water showed a $\mathrm{pH}$ of 6.8 and a hardness of $88 \mathrm{mg} / \mathrm{L}$. (with no median dissolved solids concentration noted) (USAEHA 1987). 
Regionally, the secondary source of groundwater is fractured and faulted bedrock aquifers. The most extensive bedrock aquifer types are associated with igneous and metamorphic rocks. These crystalline rocks are broadly similar in water-bearing characteristics, with well yields usually sufficient for domestic, small-scale industrial, and municipal use. The water-producing properties of crystalline rocks depend heavily on fracture characteristics, as well as the number of fractures and their degree of openness with increasing depth. The median yield of crystalline rock aquifers is about $10 \mathrm{gpm}$, with well depths ranging from $100 \mathrm{ft}$ to $200 \mathrm{ft}$. Well yields for crystalline rock aquifers in the Charles River basin are $1-50 \mathrm{gpm}$ (Walker et al. 1975), with a median well yield for the bedrock aquifers in the Lower Merrimack River basin of $10 \mathrm{gpm}$ (Gay and Delaney 1980).

As noted, the upper 1(0)-20) ft of bedrock provides the best source of water because with increased depth. fractures tend to hecome thinner and less extensive. However, aquifer yields in fractures in crystalline bedrock wells can be increased when the crystalline rocks are overlain by permeable unconsolidated deposits. Furthermore. as fractures become less predominant and less interconnected, water quality may be degraded because of mineralization.

The quality of the water from crystalline rocks in the northeastern region is variable and depends on local conditions. Generally, the water is fairly soft and only moderately mineralized. Water quality data for crystalline rocks in the region show specific conductance $\left(\mu \mathrm{mho} / \mathrm{cm}\right.$ at $\left.25^{\circ} \mathrm{C}\right)$ of 107-375, total dissolved solids (TDS) of $49-2.39 \mathrm{mg} / \mathrm{L}$, and hardness $\left(\mathrm{CaCO}_{3}\right)$ of $17-166 \mathrm{mg} / \mathrm{L}$ (Harrison et al. 1983).

\subsubsection{Local Groundwater Usage}

Most drinking water in the area comes from private wells or local municipal wells. The municipal water supply sources are shown on Figure 4. The town of Wayland has hundreds of shallow (30-40-ft deep) private water wells and four municipal wells, two of which are located within a 4-mi radius of the site (Bowkerh 1993). These municipal wells are gravel packed and $60 \mathrm{ft}$ deep; they serve approximately 12,100 people (USGS 1991), or $99 \%$ of the population.

The town of Sudbury has eight gravel-packed, 60-ft-deep municipal wells that serve approxirnately 14,000 people (USGS 1991), or approximately 99\% of the population. The town of Lincoln has two municipal wells and a surface water intake on Sandy Pond, serving approximately 5.000 people (Burnet 1993; USGS 1991). One of the town wells is located on 


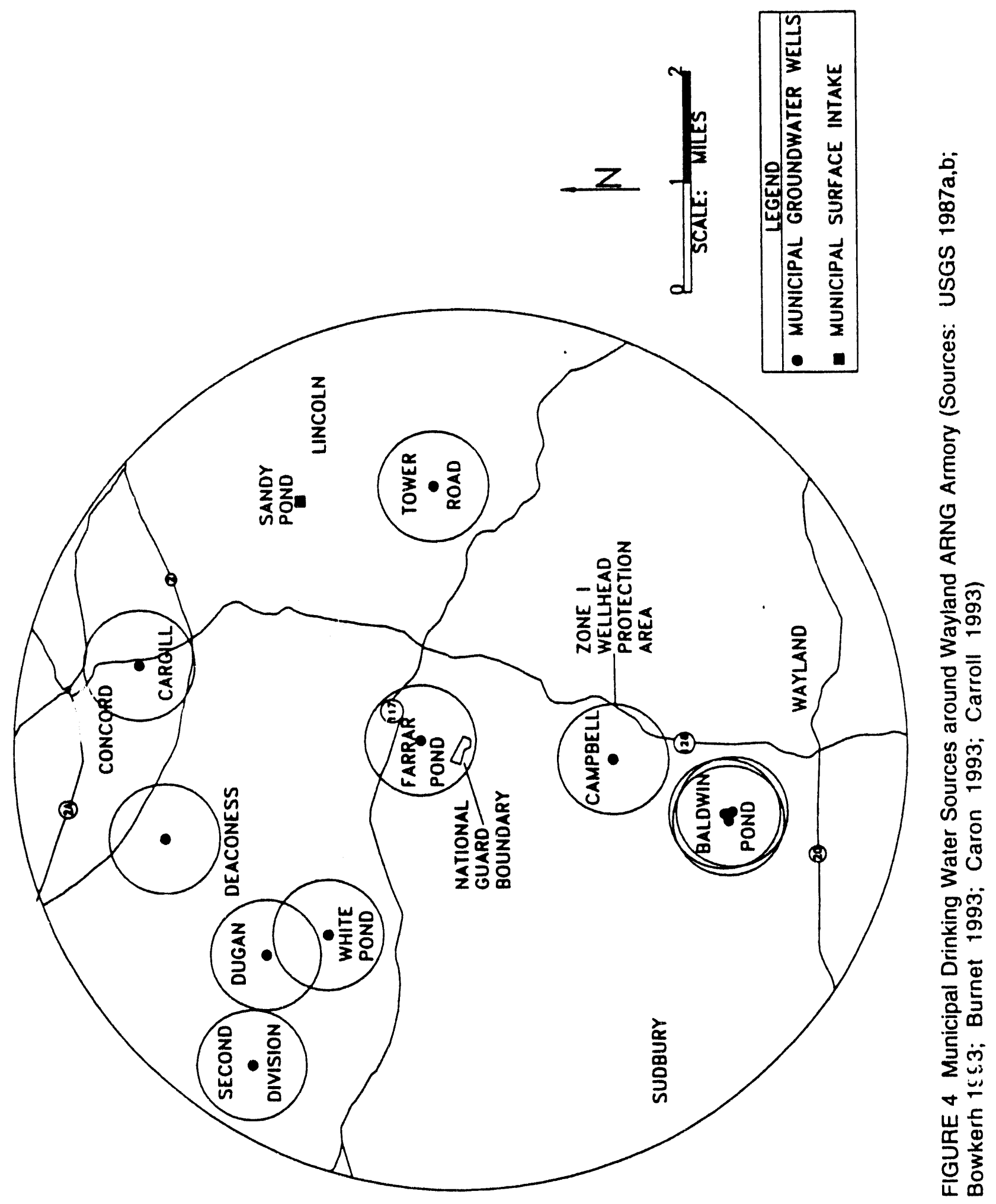


Farrar Pond, less than $0.5 \mathrm{mi}$ from the site, but this well is currently not in use because of its high iron and manganese content (Emmons 1993). Tower Road Well is gravel packed and approximately $50 \mathrm{ft}$ deep. Sandy Pond is a natural pond fed by surface runoff. Studies indicate that no groundwater recharge is found in Sandy Pond (Emmons 1993). Lincoln has hundreds of private water wells. Private wells are required to be registered, but only a portion of the older wells have heen. Therefore, it may be assumed that if 5,000 people of the total population of 7,710 are served by the public water system, the remaining 2,710 or $35 \%$ must use private wells.

The town of Concord has five municipal wells, all located within a 4-mi radius of the site, and one surface water intake (Nagog Pond), located some distance from the site. The wells are gravel packed and range in depth from 75 to $85 \mathrm{ft}$. The Cargill Well is not currently in use because of its proximity to a residence; the well is reserved for emergency supply (Concord 1993). The public water system serves approximately 16,300 people. New wells are registered with the Concord Board of Health, but older wells are not required to be registered. Therefore, an estimate of the number of people using private wells would be the remaining population not on the public water system, or 170 people (approximately $1 \%$ of the population).

The town of Weston has no municipal wells or surface water intakes because it receives its drinking water supply from the Massachusetts Water Resource Authority from the Quabbin Reservoir. Approximately $90 \%$ of the population of Weston uses the public water supply (3,100 connections). Private wells are not required to be registered in Weston, but approximately $10 \%$ of the population or 1,070 people use private drinking water wells (Mazerolle 1993).

\subsubsection{Sensitive Environments}

The Wayland Armory is located approximately $0.5 \mathrm{mi}$ from the Sudbury River and the accompanying wetlands. The site is located approximately $0.5 \mathrm{mi}$ from the northern portion of the Great Meadows National Wildlife Refuge and $0.5 \mathrm{mi}$ from the eastern boundary of the Pantry Brook State Wildlife Management Area (Figure 3).

The segment of the Sudbury River that runs past the Wayland Armory is currently under study for inclusion in the National Wild and Scenic River System (Sudbury, Assabet, and Concord Wild and Scenic River Study Act [the Act], P.L. 101-628, Title VII, \$ 702, 104 Stat. 4497, November 28, 1990). A Sudbury, Assabet, and Concord Rivers Study Committee was formed to advise the Secretary of the Interior in conducting the study and in managing the alternatives. A 
public hearing was held on October 22, 1992, at the Sudbury Town Hall. Pursuant to the Act, the study is to be submitted to the Congress no later than the end of the third fiscal year following the effective date of the Act, or sometime in the fall of 1993. No recommendation on inclusion of this segment in the National Wild and Scenic Rivers System has yet been made to the Congress.

The Great Meadows National Wildlife Refuge is composed of valuable freshwater wetlands flanking $12 \mathrm{mi}$ of the Concord and Sudbury Rivers. The U.S. Fish and Wildlife Service protects and manages Great Meadows as habitat for wildlife, with a special emphasis on migratory birds. Great Meadows consists of a variety of habitats including riverine wetlands, grasslands, and deciduous and coniferous woodlands, which provide excellent habitat for numerous nesting and migratory birds, particularly dabbling ducks and marsh and wading birds. During fall migrations, peregrine falcons and bald eagles, both endangered species, are observed occasionally at Great Meadows. Five species listed as threatened by the Massachusetts Natural Heritage Program are found at Great Meadows: Blanding's turtle, Briton's violet, the least bittern, the northern harrier, and the pied-billed grebe.

The Pantry Brook State Wildlife Management Area is owned by the Massachusetts Division of Fish and Wildlife. According to the Massachusettts Division of Fisheries and Wildlife (Lowber 1993), the blue-spotted salamander, a state-listed species of special concern, has been recorded in this area. The area is open to the public, and hunting is allowed.

Under Massachusetts regulations, the area within $0.5 \mathrm{mi}$ of a municipal drinking water well is a Zone I wellhead protection area. Therefore, nine wellhead protection areas are within a 4-mi radius of the site. These areas are shown in Figure 4. 


\section{Environmentally Significant Operations}

The PA team from Argonne identified three ESOs at the Wayland ARNG Armory: (1) an abandoned concrete UST near the dog kennels (L-18); (2) stained soil outside the current (L-9) and prior flammable storage buildings and stains on the floor of the former generator building (L-3), which run to the floor conduits and thereby to the soil beneath the floor; and (3) the hydraulic pumps for the magazine elevators and doors. Figure 5 shows the general locations of the ESOs.

\subsection{Abandoned Concrete Underground Storage Tank near the Dog Kennels}

When the site was an active Nike battery, guard dogs were kept in Building L- 18 and the surrounding pens. A small, open-sided shed with a water supply faucet was possibly used for washing the dogs, according to a former guided-missile mechanical repairman. Located approximately 25 yards to the northeast of the kennel building is a metal plate set into the grass. Under this plate is a concrete UST nearly full of liquid. Although on some site plans the small, open-sided shed is shown as an acid storage building, this area was not used for acid storage in 1966-1974. Whether acid was stored in this area prior to 1966 when the early Hercules missiles used lead-acid batteries is unknown.

\subsection{Soil Contamination}

Flammables, acids, and compressed gases are stored in Building L-9. This small shed sits on a concrete pad with no lip. Some spillage, measuring approximately $1 \mathrm{ft} \times 1 \mathrm{ft}$, is evident on the concrete step and the soil outside the door. On some site plan drawings, this building is designated liquid propellant storage. The Ajax missiles deployed at Wayland in 1955-1959 did have liquid propellants, but the Hercules missiles deployed in 1959-1974 used solid propellant, and no liquid propellants were present at that time. An unnumbered building located to the north of Building L-9, to the west of Building L-10, and to ilte east of Building L-3 was also used for flammables storage. This storage facility also shows signs of leakage or spillage, measuring approximately $2 \mathrm{ft} \times 3 \mathrm{ft}$, in front of the door. 


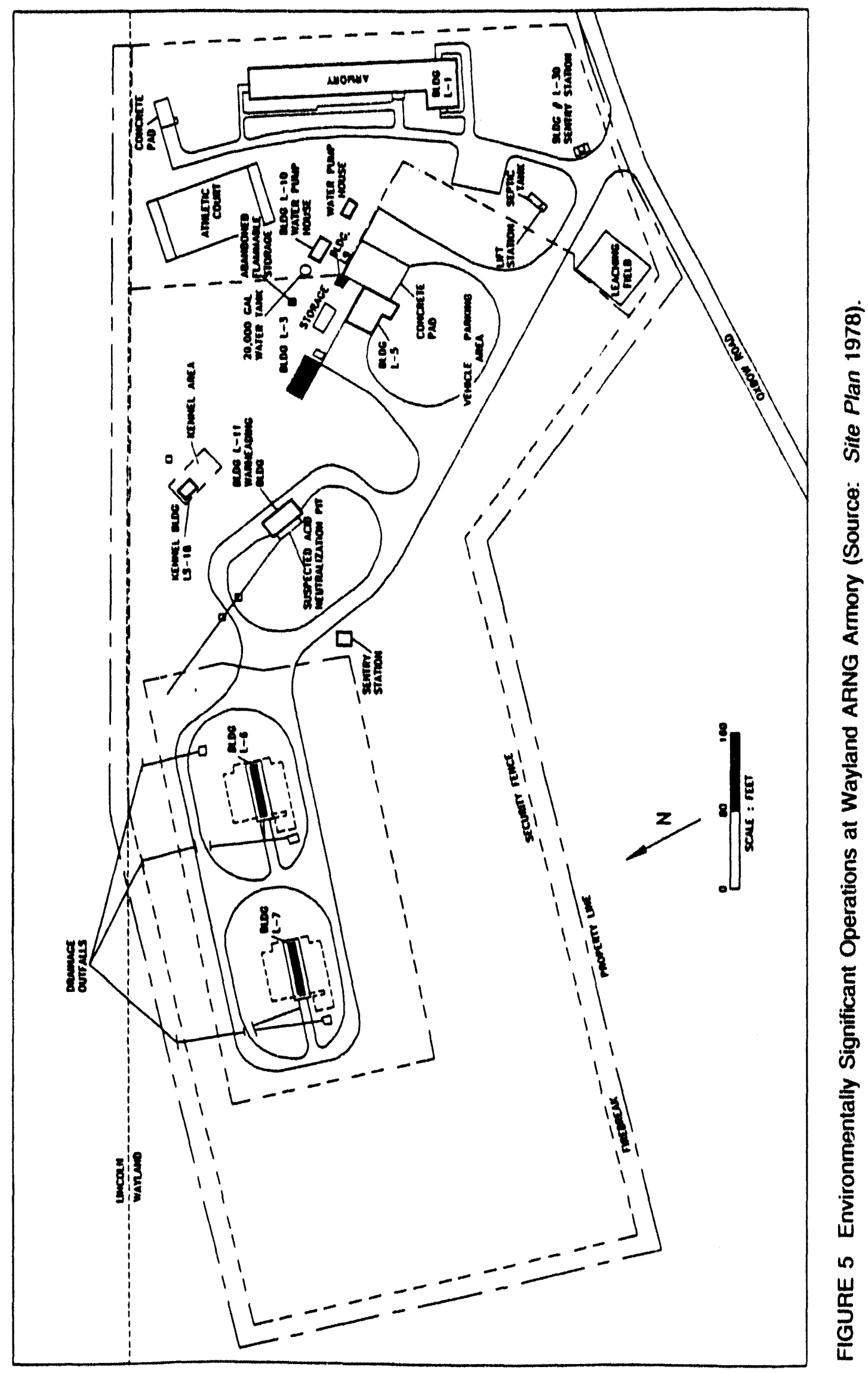


The former generator building (L-3) once housed three large electric generators. The generators were fuel oil fired, fed by a 3,000-gal UST to the north of the building. This tank fed a smaller 200-gal aboveground tank located inside the easternmost room of the building. The generators were removed in 1974, when the Nike installation was decommissioned. The concrete slab tle , of the building was cut to provide conduits for the electrical wiring measuring approximately 8 in. wide, which were then covered with wooden planks. Under the wooden planks, the earth can be seen under the building. Visible fuel oil stains originating trom the 200-gal inside aboveground tank may have entered the nearby conduit and thereby the soil. No current signs of oil contamination are visible on the soil under the floorbourds.

\subsection{Hydraulic Pumps for Magazine Elevators and Doors}

The magazines may have been abandoned with the hydraulic pumps for launchers, elevators, and door lifts in place. The hydraulic pumps may be a potential source of hydraulic tluid contamination. Although it is rusty and peeling, the stairway down to the magazine did not show evidence of water accumulation. Past observation and analysis of rainwater accumulated in the magazines showed no apparent signs of contamination (USAEHA 1987). During operation, rainwater that collected in the underground chambers was pumped out into a swale, which also carried the surface runoff to an off-site outfall located at the northern houndary of the site (USAEHA 1987). 


\section{Known and Suspected Releases}

\subsection{Releases to Groundwater}

No known releases to groundwater have occurred from the Wayland Armory. The only ESOs that may present a potential for groundwater contamination are the abundoned concrete UST located just north of the dog kennels and the hydraulic pumps for the magazine elevators and doors, possibly abandoned without being drained. The liquid in the concrete UST is not known to be or to contain a contaminant, but the potential for leakage through cracks in the concrete is probably high, because of the age of the facility. Leaks from the hydraulic pumps in the magazines may contaminate fluids that enter and collect in the bottom of the magazines. However, because the magazine sump pumps are not in service, the liquid would stay in the magazines, and leakage to the groundwater would be possible only if the concrete bunkers were to crack or otherwise become permeuble.

Although historically Nike battery sites were known to have sumps where solvents, paints. and fuels were emptied to soak into the soil, no informution exists concerning this practice at the Wayland site prior to 1966. Whether such dumping took place is unknown. In 1966-1974, such wastes were drummed and taken to Ft. Devens for proper disposal.

\subsection{Releases to Surface Water}

No known releases to surface water have come from the Wayland site. Except for storm water runoff, no fuel dispensing or other large-scale hazardous materials handling occurred at this site. In the past, liquid gathered in the bottom of the missile storage silos was pumped to two outfalls along the north side of the site. No distressed vegetation or other evidence of contamination is evident at the mouth of these outfalls. Releases could have occurred prior to 1959. when Ajax missiles using liquid propellants and JP.4 were fueled and defueled at the site, but no evidence or records of such releases exist.

Although historically Nike battery sites had acid neutralization pits and although one is shown on site drawings for Wayland, no information is available concerning this praclice at the site prior to 1966. Whether such a pit exists or was used is unknown. No acia neutralization took place from 1966 to 1974. 


\subsection{Releases to Soll}

Small releases to the soil apparently occurred from the hazardous materials storage building (L-9) and an unnumbered thammables storage building (abandoned) on the site. The stain in front of Building L-9 is approximately $1 \mathrm{ft} \times 1 \mathrm{ft}$. The stain in front of the abandoned flammables storage building measures approximately $2 \mathrm{ft} \times 3 \mathrm{ft}$. The commodity spilled or leaked from these buildings is unknown, but because they are storage buildings for flammables or hazardous materials, the leaked muterial should be assumed be to an environmental contaminant.

\subsection{Releases to Air}

No known releases to the air have occurred from this site.

\subsection{Other Releases}

No other known releases have come from this site. 


\section{Human and Environmental Receptors}

\subsection{Groundwater}

Both the storm and overtlow runoff systems discharge directly to subsurface recharge areas for the local unconfined glacial aquifer. Records indicate that the water levels in the glacial $y$ inifer in the Wayland area can be within $15 \mathrm{ft}$ of the surface (Socolow et al. 1990). These levels allow leakage from the concrete UST or the silos to contact the saturated aquifer material at the site.

No intormation is available on the direction or velocity of the groundwater how under the site: however, because of the shallow depth of the surficial aquifer, contamination would affect municipal and private drinking water wells in the area. Through infiltration and seepage, groundwater contamination could reach wetlands surrounding ti. Sudbury River and the marshes that compose the Great Meadows National Wildlife Refuge and Pantry Brook State Wildlife Management Area. assuming the direction of groundwater flow mimics surface runoff.

\subsection{Surface Water}

The overall surface water runoff systems have been engineered to discharge directly to surface rock blankets exiting the site to the north. Those that thow to the south would enter the Wayland storm sewer system along Oxbow Road. Those flowing to the west would enter the storm sewer system for the new housing development currently being built within $500 \mathrm{ft}$ of the site. Runoff to the east would encounter the yard of a nearby residence $(200 \mathrm{ft})$. In periods of very high runoff to the north, discharges could enter the storm sewer system for the residential developments of Farrar Pond Village or Lincoln Ridge on Furrar Pond, or the discharges could travel downgradient along erosion pathways to Farrar Pond. However, the residential developments and storm sewer drainage systems may prevent direct flow to Furrar Pond, the Sudbury River, or the Great Meadows National Wildlife Refuge except in times of exceptionally heavy surface drainage.

\subsection{Soll}

The Wayland site is controlled. No one lives on the site. Soil contamination receptors would be limited to those working on the site. Only four people work on-site permanently, and all 
other personnel come for weekend drills. Wind-blown contamination due to the prevalent westerly winds could affect nearby residences directly north, east, and south of the site.

\subsection{Alr}

If air pollutants were released from the Wayland site, the prevalent westerly winds could affect nearby residences directly north, east, and south of the site.

\subsection{Other Receptors}

The Great Meadows National Wildlile Refuge and the Pantry Brook State Wildlife Management Area are located $0.5 \mathrm{mi}$ to the west of the site. The wildlife habitut protected by these two tracts could be affected by runolf reaching the marshes. However, intervening housing developments with stormwater drainage systems might prevent the direct llow of contaminants from the site to these areas. Groundwater contamination, however, could enter these marshes through infiltration of the surficial aquifer, if the groundwater flow were in a westerly direction. No studies are available to determine the direction of groundwater llow at this site. 


\section{Prellminary Assessment Findings and Conclusions}

\subsection{Summary of Preliminary Assessment Findings}

The Wayland ARNG Armory is a 29.2 -acre site locuted approximately $18 \mathrm{mi}$ west of Boston, in Wayland, Massachusetts, in Middlesex County. The current primary ESOs are (1) an abandoned concrete UST near the dog kennels (L-18); (2) stained soil outside the current (L-9) and prior flammable storage buildings and stains on the floor of the former generator building (L.3). which lead to lloor co. Juits and thereby to the soil beneath the huilding: and (3) the hydraulic pumps for the magazine launchers, elevators, and doors.

\subsection{Recommendations for Further Action}

The primary objective of the PA is to identify and evaluate ESOs that would result in either (1) immediate action, (2) site investigation, or (3) no further PA/IRP action. Generally, the available information indicalcs that the Wayland Armory presents a low level of threat to human health and the environment. However, on the basis of the information made available to Argonne, the following areas deserve further consideration to ensure protection of the lecal community and the environnent:

- Stains to the soil outside the current flammable storage building (L-9) and outside the old, abandoned flammable storage building. These areas should be investigated and the contuminated soil removed.

- Three old transformers located in the current ambulance supply building (L.-3). Although no evidence of leakage from these transformers exists, the older transformers could contain transformer oil with polychlorinated biphenyls (PCBs), and these transformers should be removed and cliecked.

- A 55-gal rusting drum containing an unknown liquid (with an open bung), which is sitting by the door of the current ambulance supply building (1.-3). This liquid should be removed, characterized, and disposed of properly. 
- A metal plate in the ground covering a concrete UST to the northeast of the dog kennel (L-18), with liquid visible through the opening to within $2 \mathrm{ft}$ of ground level. This UST should be emptied and the liquid characterized for hazardous constituents. If the liquid is an environmental pollutant, the tank should be removed and the surrounding soil tested. If the liquid is simply rainwater accumulation, the tank should be filled to prevent further accumulation of fluids.

- A small transformer and an empty 1,000-gal aboveground tank located in the water pump building (L-10). No evidence of leakage from the transtormer exists, but because older transformers could contain PCB transformer oil, the transformer should be removed and checked. The aboveground tank should be checked for hazardous constituents.

- Hydraulic pumps for the magazine elevators and doors possibly abandoned in the magazines without draining, thereby creating the possibility of hydraulic tluid leaks into the magazines. These hydraulic pumps should be removed and checked, because the older pumps could contain PCB hydraulic fluids.

Although no record or evidence indicates past releases of contaminants or improper disposal activities at the Wayland Armory, the typical history, military organization, and physical components of the Nike missile systems (McMaster et al, 1984; Law Engineering Testing Company 1986) provide a basis for ceriain inferred conclusions about possible environmental concerns at such a launcher site. These concerns include the following: (1) the disposal of liquid wastes (solvents, paints, petroleum, oil, and lubricants) to sumps near the former generator building ( $L-3$ ), warheading building (L-II), or missile assembly building (L-5): (2) the disposal of acid waste into an acid neutralization pit near the warheading building (L-11), with discharges to the storm runoff outfall to the north of the site; (3) the discharge of hydraulic fluid and other wastes from the tottom of the missile magazines through sumps pumping to two outfalls to the north of the site; and (4) possible Ajax missile fuel spills from the fueling area just northeast of the warheading building (L- 11 ), which could have entered the storm runoff outfall to the nor $h$ th the site. Investigation or sampling of these areas may be warranted. 


\section{Sources of Information}

\subsection{References}

Bowkerh, L., 1993, verbal communication from Lewis Bowkerh, Wayland Town Surveyor, to S. Flaim, Argonne National Laboratory, Argonne, Illinois, April 26.

Burnet, J., 1993, verbal communication from Jane Burnet, Engineering Department, Lincoln. Massachusetts, to S. Flaim, Argonne National Laboratory, Argonne, Illinois. April 26.

Caron, M., 1993, verbal communication from Maurice Caron, Manager, Concord Water and Sewer Division, to S. Flaim, Argonne National Laboratory, Argonne, Illinois, April 26.

Carroll, R.. 1993, verbal communication from Richard Carroll, Superintendent, Sudbury Water District, to S. Flaim, Argonne National Laboratory, Argonne, Illinois, April 26.

Concord, 1993, Annual Report for the Town of Concord. Massachusetts, for the Year Ending December 1992.

Emmons, F., 1993, verbal communication from Frank Emmons, Lincoln Engineering Department. to R. Haffenden, Argonne National Laboratory, Argonne, Illinois, June 29.

EPA, 1991, Guidance for Performing Preliminary Assessments under CERCLA, Publication 9345.0-01 A, Office Emergency and Remedial Response, Office of Solid Waste and Emergency Response, U.S. Environmental Protection Agency, Washington, D.C.

Gale Research, Inc., 1985, Climates of the States, National Oceanic and Atmospheric Administration. Narrative Summaries, Tables and Maps for Each State with Overview of State Climatologist Programs, Third Edition, James A. Ruffner, Editor.

Gay, F.B., and D.F. Delaney, 1980, Hydrology and Water Resources of the Lower Merrimack River Basin, Massachusetts, from Concord River, Lowell to Plumb Island. Newlury. U.S. Geological Survey Hydrologic Investigations, Atlas HA-616. 
Grading Plan, 1960, Drawing Number 16-06-151, Boston Defense Area Nike Battery 73, Lincoln-Wayland, Massachusetts, prepared for U.S. Army Corps of Engineers by Clarkeson Engineering Co., Inc., Boston, Massachusetts, May 1958, revised March 1, 1960.

Harrison. W., et al., 1983, Geology, Hydrology, and Mineral Resources of Crystalline Rock Areas of the Northeastern United States, ANL/ES-136, Part 1, Argonne National Laboratory, Argonne, Illinois, prepared for the U.S. Department of Energy.

Holland, W.R., 1980, The Surficial Geology of the Billerica Quadrangle. Middlesex County, Massachusetts, Master's Thesis, Boston University.

Koteff. C., 1964, Surficial Geology of the Concord Quadrangle, Massachusetts, U.S. Geological Survey Map GQ-331.

Law Engineering Testing Company, 1986, Final Report, Investigation of Former Nike Missile Sites for Potential Toxic and Hazardous Waste Contamination, Volume I, Les-Government Services Division, Atlanta, Georgia, March.

Layout and Grading Plan, 1958, Drawing Number 16-06-124, Boston Defense Area Nike Battery 73, Lincoln-Wayland, Massachusetts, prepared for U.S. Army Corps of Engineers by Clarkeson Engineering Co., Inc., Boston, Massachusetts, January, revised April 28.

Lowber, D., 1993, personal communication, Massachusetts Division of Fisheries and Wildlife, Boston, Mass.

Mazerolle, R., 1993, verbal communication from Robert Mazerolle, Weston Water Department, to R. Haffenden, Argonne National Laboratory, Argonne, lllinois, June 29.

McMaster, B.N., J.B. Sosebee, W.G. Fraser, K.C. Govro, C.F. Jones, S.A. Grainger, and K.A. Civitarese, 1984, Historical Overview of the Nike Missile System, Environmental Science and Engineering, Inc., Gainesville, Florida, December.

Site Plan, Nike Site B-73, Wayland, Mass., 1978, Drawing Number D295-78-0000. Sheet 2 of 2. The Commonwealth of Massachusetts Military Division, October 29. 
Socolow, R.S., et al., 1990, Water Resources Data, Massachusetts and Rhode Island, Water Year 1990, U.S. Geological Survey Water Data Report MA-RI-90-1.

USAEHA. 1987. Water Quality Engineering Study No. 31-24-0774-87, Potable Water System Survey. Massachusetts Army National Guard Wayland and Rehobeth, Massachusetts, U.S. Army Environmental Hygiene Agency, April.

USGS, 1987a, Framingham Quadrangle, Massachusetts, Middlesex County, U.S. Geological Survey Map, 7.5-Minute Series (Topographic).

USGS. 1987b, Maynard Quadrangle, Massachusetts, Middlesex County, U.S. Geological Survey Map, 7.5-Minute Series (Topographic).

USGS, 1991. Public Water-Supply in Massachusetts, 1986, U.S. Geological Survey, Open-File Report 91-86, Boston, Massachusetts.

Walker, E.H. et al., 1975, Hydrology and Water Resources of the Charles River Basin, Massachusetts, U.S. Geologic Survey Hydrologic Investigations, Atlas HA-554.

\subsection{Other Sources}

Fagan, G., 1993, verbal communication from Gerald Fagan, Town Engineer. Weston, Massachusetts, to S. Flaim, Argonne National Laboratory, Argonne, Illinois, April 26.

Frimpter, Michael H., 1987, Massachusetts Groundwater Quality, U.S. Geologic Survey Open-File Report 87-0731.

Gale Research, Inc., 1992, Weather of U.S. Cities, Fourth Edition, Frank E. Bair, Editor. 
Appendix:

Interview Information 


\section{Appendix:}

\section{Interview Information}

\section{Individuals Interviewed}

Environmental Protection Specialist

Massachusetts Army National Guard

Headquarters

Camp Curtis Guild

25 Haverhill Street

Reading, Massachusetts

(617) 944-0500 × 2525

Wayland Town Surveyor

Wayland Town Offices

Wayland, Massachusetts

(508) 358-770।

Staff Member

Engineering Department

Lincoln Town Offices

Lincoln, Massachusetts

(617) 259.8850

Manager

Water and Sewer Division

Department of Public Works

Town of Concord

133 Keyes Road

Concord, Massachusetts 01742
Superintendent

Sudbury Water District

199 Raymond Road

Sudbury, Massachusetts 01776

(508) 443-66()2

Engineering Department

Lincoln Town Otfices

Lincoln, Massachusetts

(617) 259-8850

Town Engineer

Town Hall

Weston, Massachusetts 02193

(617) 893-7320

Water Department

Town Hall

Weston, Massachusetts (2) 193

(617) 893-236.3

Former Guided-Missile Mechanical Repairman Readiness NCO

Natick Massachusetts National Guard Facility Natick, Massachusetts

(508) 655-5982

\section{Argonne Investigators}

Rebecca A. Haffenden

(708) 252-5159

Sam Flaim

(303) $986-1140$

Michael Krokosz

(708) 252-5027 

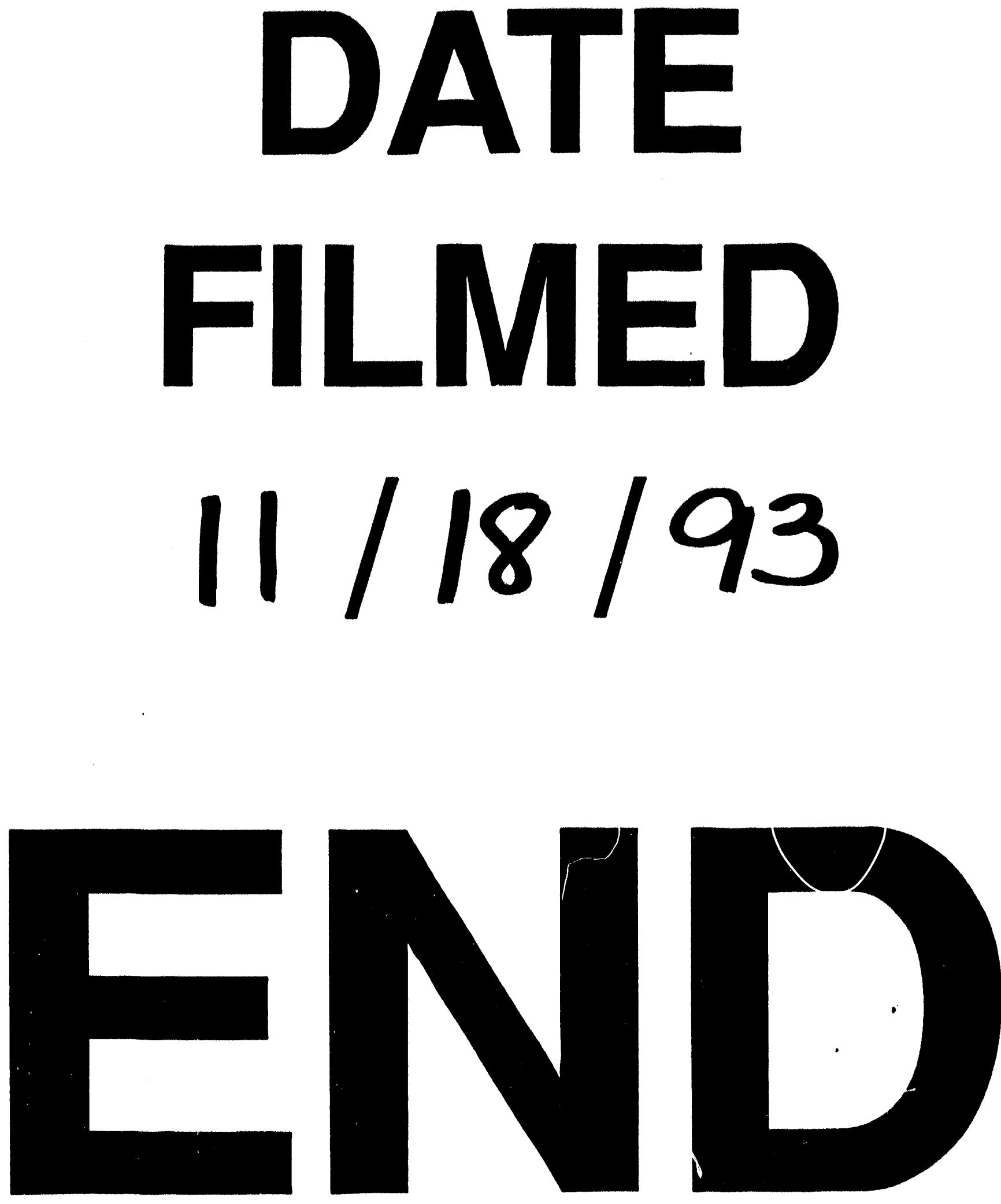
$\overline{7}$

(
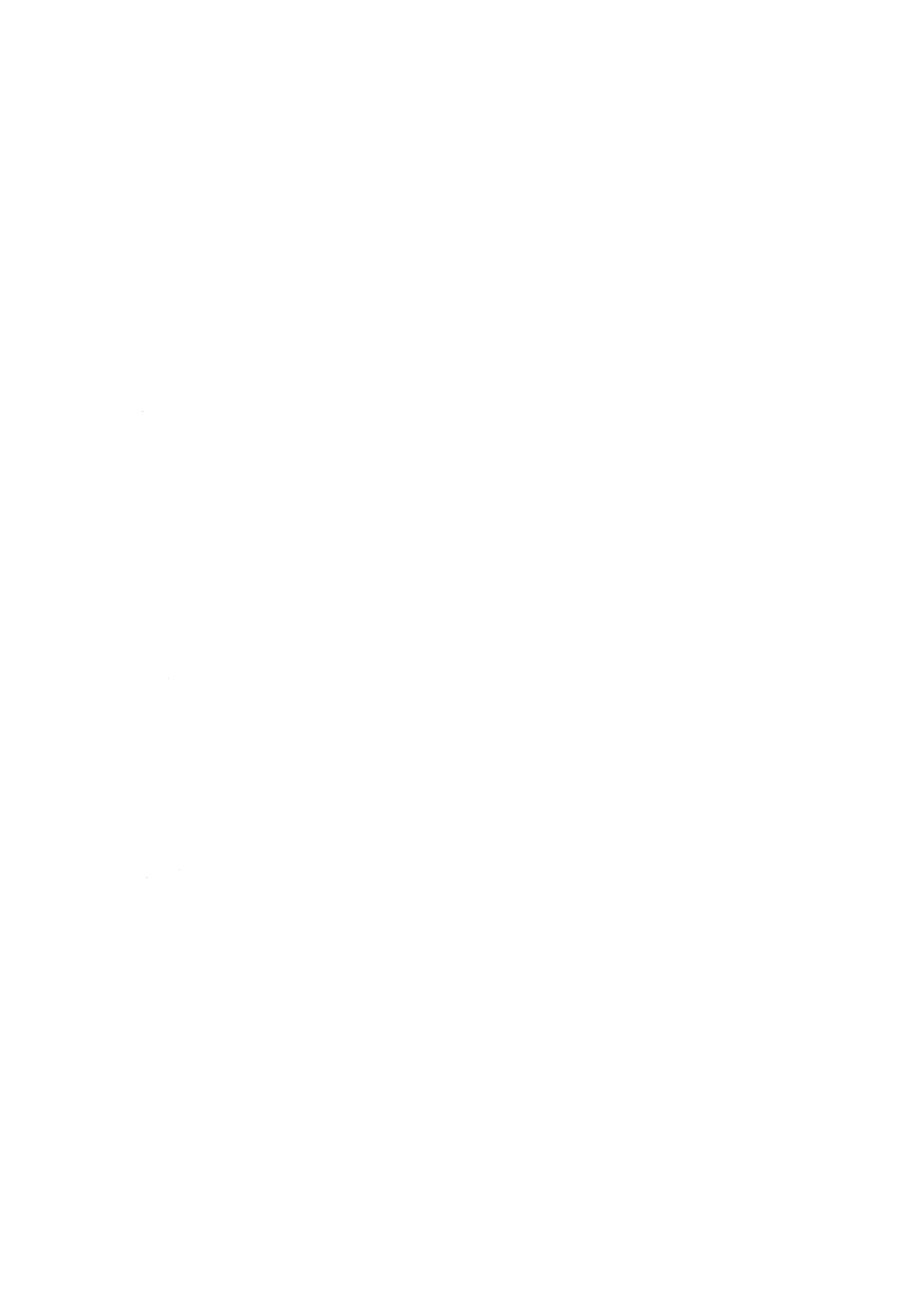